Sains Malaysiana 50(9)(2021): 2791-2817

http://doi.org/10.17576/jsm-2021-5009-24

\title{
Diversification of Agricultural Areas in Indonesia using Dynamic Copula Modeling and K-Means Clustering
}

(Pempelbagaian Kawasan Pertanian di Indonesia menggunakan Pemodelan Copula Dinamik dan Pengelompokan K-Min)

Atina AhdikA*, Mujiati Dwi Kartikasari, SeKti Kartika Dini \& InTAN RAMAdhani

\section{ABSTRACT}

Agriculture is one of the main pillars of economic growth in Indonesia. Failure in this sector can result in faltering economic stability of the country. Thus, to minimize these failures, mapping of areas with particular commodity potential is needed. One of the main factors affecting the growth of crops is rainfall. Therefore, this paper aims to model the potential distribution of commodity growth based on rainfall precipitation using dynamic copula. The modeling results are then used as a basis for grouping the potential of food crop commodities in Indonesia. The determination of the group was carried out using the $k$-means clustering method. We expect that the result of the modeling can provide an overview for farmers or the government to make policies related to the optimization of Indonesia's agricultural sector. This result will enable the government to offer facilities that can minimize agricultural losses, such as superior seeds that are resistant to weather changes and the provision of training for enhancing farming skills. In addition, it is also suggested to diversify farm areas to reduce the failures due to dependence on a single agricultural product.

Keywords: Agriculture; diversification; dynamic copula; k-means clustering

\section{ABSTRAK}

Pertanian adalah satu daripada tonggak utama yang mendorong ekonomi di Indonesia. Kegagalan dalam sektor ini boleh mengakibatkan kestabilan ekonomi di negara ini merosot. Oleh sebab itu, untuk mengurangkan kegagalan ini, diperlukan pemetaan kawasan dengan potensi komoditi tertentu. Satu daripada faktor utama yang mempengaruhi pertumbuhan tanaman adalah hujan. Oleh sebab itu, makalah ini bertujuan untuk memodelkan potensi penyebaran pertumbuhan komoditi berdasarkan curahan hujan menggunakan model copula dinamik. Hasil pemodelan kemudian digunakan sebagai dasar untuk mengelompokkan potensi komoditi tanaman makanan di Indonesia. Penentuan kelompok dilakukan dengan kaedah pengelompokan k-min. Penulis mengharapkan hasil pemodelan dapat memberikan gambaran umum kepada petani atau kerajaan untuk membuat polisi yang berkaitan dengan pengoptimuman sektor pertanian Indonesia. Kerajaan dapat menawarkan kemudahan yang dapat meminimumkan kerugian dalam pertanian, seperti benih unggul yang tahan terhadap perubahan cuaca dan pemberian latihan kepada petani untuk meningkatkan kemahiran mereka. Sebagai tambahan, dicadangkan juga supaya petani mempelbagaikan kawasan pertanian untuk mengurangkan kegagalan akibat kebergantungan pada satu produk pertanian sahaja.

Kata kunci: Copula dinamik; pempelbagaian; pengelompokan k-min; pertanian

\section{INTRODUCTION}

Indonesia is one of the world's major agricultural nation with farming as one of the key sectors. Based on data from the Indonesian Central Bureau of Statistics (Badan Pusat
Statistik/BPS-Statistics Indonesia), the number of farmers in Indonesia reached 33.4 million in 2018 (Team of SUTAS2018 2018). The leading commodity of agricultural sector in Indonesia is the food crop sector, which consists 
of grains, maize, tubers, and beans. The total production of Indonesia's food crop sector consisted of 83,037,150 tons of grains, 30,055,623 tons of maize, 19,447,459 tons of tubers, and 746,916 tons of beans (Ministry of Agriculture 2018). However, agricultural businesses are very prone to losses due to extreme weather and agricultural pests. One of the main factors affecting crop growth is weatherrelated variables, such as rainfall, which is a dynamic condition. Thus, the step to minimize losses in the food crop sector involves mapping areas based on commodity potentials.

There have been many studies on the impact of weather and climate change on crop growth and productivity. For instance, Tao et al. (2009) analyzed the variability of the crop yields in response to weather changes using Bayesian probability inversion and Markov Chain Monte Carlo (MCMC). Similarly, AntwiAgyei et al. (2012) evaluated the impact of drought on crop production vulnerability at a national and regional scale by applying a crop drought vulnerability index and socioeconomics indicator approach. Meanwhile, Bezabih and Di Falco (2012) and Turvey (1991) used single index model to model crop production risk at household level. Bandara and Cai (2014) identified the impact of climate change on crop productivity, food price, and food security in South Asia using a global dynamic computable general equilibrium model. Adimassu et al. (2014) suggested farmers' strategy to respond to the decrease in crop production due to the decline in rainfall. In addition, recent studies by Alidoost et al. (2019) evaluated the complex dependence of extreme climate indices and crop-related variables: yield, production, and price of crop using a comprehensive copula-based analysis. Likewise, Vogel et al. (2019) analyzed the impacts of climate extreme on yield anomalies of maize, soybeans, rice, and spring wheat at a global scale using random forest method, while Ribeiro et al. (2019) analyzed the risk of drought hazard on agricultural systems to mitigate drought-related crop losses using copula.

There are many methods to identify and model the impact of weather on crop production, one of which of increasing popularity is by using the copula model. Copula model, introduced by Sklar (1959), is a multivariate distribution function that pairs interrelated variables. Many researchers have conducted studies to identify the relationship between crop productivity and its economic consequences due to the influential variables, such as weather and climate condition. For example, $\mathrm{Xu}$ et al. (2010) assessed the agricultural financial losses based on the joint occurrence of unfavorable weather conditions, i.e., cumulative rainfall index, potential drought, and growing degree days; an index to measure the impact of temperature on the growth and the development of plants during a growing season in different locations using Archimedean copula. In addition, Cong and Brady (2012) evaluated the interdependence between temperature and rainfall in Scania, Sweden. They also proposed further research on the relationship between these two variables on agricultural production using copula. Meanwhile, Li et al. (2015) estimated the uncertainty of the drought risk to the meteorological disaster risk of crop using the Archimedean copula function, while Nguyen-Huy et al. (2018) investigated the Spatio-temporal effect of multiple climate indices on the variability of wheat yield in Australia using the vine copula approach.

Due to the weather data's nature, especially the rainfall data, we assume that there is a temporal dependence between rainfall and crop production. Therefore, this study seeks to evaluate the structure of dependence between rainfall variables and food crop production in 34 provinces in Indonesia using a dynamic copula model. Unlike the standard static copula model, the dynamic copula model provides a time variation in its parameter to demonstrate the temporal dependence between variables (Ausin \& Lopes 2010; Jondeau \& Rockinger 2006; Manner \& Reznikova 2012; Patton 2006). We then applied the dynamic copula's estimated parameters to predict the food crop productions of paddies and secondary crops. Furthermore, the grouping of regions was carried out to identify the potential food crop commodities in each province using $\mathrm{k}$-means clustering. This method is selected because it is a simple and elegant method for partitioning $n$ data into $k$ non-overlapping clusters. The first step in clustering using k-means is to determine the number of $k$ groups.

The k-means algorithm will assign each observational data exactly into one of the $k$ clusters (James et al. 2013). To obtain good clustering results, we have to process the algorithm multiple times by differentiating the cluster initiative center. The time complexity of the k-means algorithm is $O(n k t)$, where $n$ is the total number of objects, $k$ is the number of clusters, and $\mathrm{t}$ is the number of iterations. Normally, $k<<n$ and $t$ $<<n$. Therefore, the method is relatively scalable and efficient in processing large data sets. Scalability is one 
of the typical clustering requirements in data mining because many clustering algorithms work well with small datasets containing fewer than a few hundred data objects. As clustering data in large datasets can cause biased results, highly scalable clustering algorithms are needed (Han et al. 2012). The results of this modeling are intended for providing farmers or government with general information to decide strategies or make policies related to the provision of facilities that can minimize agricultural losses. Besides, using these modeling results, the farmers or government can undertake diversification efforts in agricultural areas to lower losses in one particular type of agricultural product. In this paper, we predict the production of the food crops in Indonesia by identifying the temporal dependence structure between rainfall and crop production data using dynamic copula. We also group the regions based on the potential of the predicted production, which involves the effect of rainfall to crop production using k-means clustering.

The rest of the paper is organized as follows. Next section reviews the concept and properties of dynamic copula and k-means clustering and the modeling procedures. Subsequent section provides the result of the data analysis and discussion. The conclusion of the study is presented in the last section.

\section{MATERIALS AND METHODS}

\section{DYNAMIC COPULA MODEL}

As the extension of the static/conventional copula models, the dynamic copula model embeds a time variation on its parameter. Suppose that there are two types of historical data: the marginal variables which consist of the rainfall data, notated by $X$, and the food crop production, notated by $Y_{t i j}$, where $i$ represents the food crop commodities $i=1,2, \ldots, 9, j$ represents the provinces in Indonesia $j=1,2, \ldots, 34$, and $t$ represents the time of the observation $t=1970,1971, \ldots, 2017$. First, we performed a marginal modeling using the univariate time-series model. Let $u_{t}=F\left(x_{t}\right)$ and $v_{t, i j}=F\left(Y_{t, i j}\right)$ be the cumulative distribution functions of the marginal variables and $H\left(x_{t}, Y_{t, i j}\right)$ is the joint distribution of $X_{t}$ and $Y_{t, i j^{\prime}}$. There exists a dynamic copula $C($.$) such that$ (Sklar 1959)

$$
H\left(x_{t}, Y_{t, i j}\right)=C\left(u_{t}, v_{t, i j}\right)
$$

In this paper, we use the dynamic Gaussian $C^{G a}($.$) , Clayton$ $C^{C l}($.$) , Gumbel C^{G b}($.), and Symmetry Joe-Clayton (SJC) $C^{S J C}($.$) copulas defined by$

$$
\begin{gathered}
C^{G a}\left(u_{t}, v_{t, i j}\right)=\int_{-\infty}^{\Phi^{-1}\left(u_{t}\right)} \int_{-\infty}^{\Phi^{-1}\left(v_{t, i j}\right)} \frac{1}{2 \pi \sqrt{\left(1-\rho_{t}\right)}} \exp \left(\frac{-\left(r^{2}-2 \rho_{t} r s+s^{2}\right)}{2\left(1-\rho_{t}^{2}\right)}\right) d r d s \\
-1<\rho_{t}<1 \\
C^{C l}\left(u_{t}, v_{t, i j}\right)=\left(u_{t}^{-\theta_{t}}+v_{t, i j}^{-\theta_{t}}-1\right)-\frac{1}{\theta_{t}}, 0<\theta_{t}<+\infty \\
\left.C^{G b}\left(u_{t}, v_{t, i j}\right)=\exp \left(-\left[-\left(\ln u_{t}\right)^{\theta_{t}}+\left(-\ln v_{t, i j}\right)^{\theta_{t}}\right]\right]_{\theta_{t}}^{1}\right), 1<\theta_{t}<+\infty \\
C^{S J C}\left(u_{t}, v_{t, i j}\right)=0.5\left(C^{J C}\left(u_{t}, v_{t, i j}\right)+C^{J C}\left(1-u_{t}, 1-v_{t, i j}\right)+u_{t}+v_{t, i j}-1\right)(5)
\end{gathered}
$$

respectively, where $C^{J C}($.$) is Joe-Clayton copula which$ is given by

$$
\begin{gathered}
C^{J C}\left(u_{t}, v_{t, i j}\right)=1-\left\{1-\left(\left[1-\left(1-u_{t}\right)^{\kappa_{t}}\right]^{-\gamma_{t}}+\left[1-\left(1-v_{t, i j}\right)^{\kappa_{t}}\right]^{-\gamma_{t}}-1\right)^{\frac{1}{\gamma_{t}}}\right\}^{\frac{1}{\kappa_{t}}} \\
\kappa_{t}=\frac{1}{\log _{2}\left(2-\tau_{t}^{U}\right)}, \gamma_{t}=-\frac{1}{\log _{2}\left(\tau_{t}^{L}\right)}, 0<\tau_{t}^{U}, \tau_{t}^{L}<1
\end{gathered}
$$

Suppose that $\Omega_{t}=\left\{p_{p}, \theta_{t}^{C l}, \theta_{t}^{G b},\left(\tau_{t}^{U}, \tau_{t}^{L}\right)\right\}$ is the parameter space of dynamic Gaussian, Clayton, Gumbel, and SJC copula, respectively. The autoregressive process defines the time variation embedded in the parameter of dynamic copula for each copula as follows (Manner \& Reznikova 2012; Patton 2006)

$$
\Omega_{t}=\Lambda\left(\omega+\beta \Omega_{t-1}+\alpha \cdot \frac{1}{m} \sum_{k=1}^{m}\left|u_{t-k}-v_{t, i j-k}\right|\right)
$$

where $\Lambda(x)$ is; $\left(1-e^{-x}\right)\left(1+e^{-x}\right)^{-1}$ for Gaussian copula, $e^{x}$ for Clayton copula, $e^{x}+1$ for Gumbel copula, and $(1+$ $\left.e^{-x}\right)^{-1}$ for SJC copula. Parameter estimation is obtained by a maximum likelihood method with the likelihood function given by

$$
L\left(\Omega_{t}, X_{t}, Y_{t, i j}\right)=\sum_{t=1}^{T} \log \left(c\left(u_{t}, v_{t, i j}\right)\right)
$$

where $c($.$) is the copula density function. The best$ dynamic copula model is selected based on the smallest AIC value. 
After obtaining the estimated parameter of the dynamic copula model, we generated new pairs of the marginal variables, which involves the dependence between the two variables through dynamic copula modeling. The procedures are as follows: First, generate a new pair of marginal variables based on dynamic copula model $\left(\hat{u}_{t}, \hat{v}_{t, i j}\right)$. Second, transform the new pairs into a new time-series data, which involves the structure of dependence between the marginal variables using the inverse transform of the cumulative distribution function of each marginal variable such that

$$
\begin{aligned}
\hat{X}_{t} & =F^{-1}\left(\hat{u}_{t}\right) \\
\hat{Y}_{t, i j} & =F^{-1}\left(\hat{v}_{t, i j}\right)
\end{aligned}
$$

After getting a new pair of marginal variables based on dynamic copula modeling, we conducted a grouping of the areas based on the potential growth of the commodities using k-means clustering.

\section{K-MEANS CLUSTERING}

$\mathrm{K}$-means clustering is one of the non-hierarchical clustering methods used to divide existing data into some clusters. The k-means clustering algorithm is conducted based on the following steps (Agusta 2007; Haraty et al. 2015): 1. Determine the number of clusters $k$.2. Determine the centroid of each cluster, representing the coordinates of the items that will be clustered, by choosing a random element. 3. Calculate the next centroid cluster using the following formula

$$
v=\frac{\sum_{k=1}^{n} Y_{t, i j}(k)}{n}, n=1,2,3, \ldots
$$

where $v$ is the cluster centroid; $Y_{t, i j}(k)$ is the $k$ - $h$ object; and $n$ is the number of items that are member of the cluster. 4. Calculate the distance of each object to each centroid in each cluster with Euclidean distance

$$
d_{p k}=\sqrt{\sum_{k=1}^{s}\left(Y_{t, i j}(p k)-Y_{t, i j}(q k)\right)^{2}}
$$

where $d_{p k}$ is the Euclidean distance of the $p$ - th and $q$ th object data; $s$ is the number of variables; $Y_{t, i j}(p k)$ is the $p$ - th data object in the $k$ - th variable; and $Y_{t, i j}(q k)$ is the $q$ - th data object in the $k$ - $t h$ variable. 5. Allocate each object to the most similar group based on the closest distance to the centroid. 6. Calculate the average value of objects in the same centroid to determine the position of the new centroid $C_{k}$.

$$
C_{k}=\frac{1}{n_{k}} \sum d_{i}
$$

where $n_{k}$ is the number of members in cluster $k$ and $d_{i}$ is the number of groups $k$. 7. Repeat steps 5 and 6 until the centroid reaches a fixed position.

The absence of multicollinearity, i.e. a linear relationship between research variables, in the research variables is the assumption that must be fulfilled in cluster analysis. Bartlett test can be used to determine whether there exists multicollinearity in the research variables or not.

If multicollinearity exists between variables, we need to reduce the data dimensions. However, this step does not reduce the data's important information. Principal Component Analysis (PCA) is a high dimensional data reduction technique that uses dependencies between variables to form low dimensions without losing a lot of information from the dataset (Dash et al. 2014). Thus, several orthogonal significant components will be created. The principal component $(P C)$ will be used as a new variable for input cluster analysis (Juaeni 2014).

The principal component is defined as a variable transformation in the form of a linear combination of variables (Johnson \& Wichern 2007). The steps in forming the $P C$ are as follows: 1 . Determine a matrix which consists of the commodities data $\left(Y_{t, i j}\right)$. 2. Calculate the covariance matrix $(\Sigma)$ to determine the eigenvalues $(\lambda)$. 3 . Based on the eigen matrix $A$, the principal component $(Z)$ is formed as follows:

$$
\begin{aligned}
& Z=\left[\begin{array}{c}
Z_{1} \\
\ldots \\
Z_{p}
\end{array}\right], A=\left[\begin{array}{ccc}
a_{11} & \ldots & a_{1 p} \\
\ldots & \ldots & \ldots \\
a_{p 1} & \ldots & a_{p p}
\end{array}\right], Y_{t, i j}=\left[\begin{array}{c}
Y_{1, \mathrm{ij}} \\
\ldots \\
Y_{p, i j}
\end{array}\right] \\
& P C_{1}=Z_{1}=a_{11} Y_{1, \mathrm{ij}}+a_{12} Y_{2, \mathrm{ij}}+\cdots+a_{1 p} Y_{p, i j} \\
& P C_{2}=Z_{2}=a_{21} Y_{1, \mathrm{ij}}+a_{22} Y_{2, \mathrm{ij}}+\cdots+a_{2 p} Y_{p, i j} \\
& \cdot \\
& P C_{p}=Z_{p}=a_{p 1} Y_{1, \mathrm{ij}}+a_{p 2} Y_{2, \mathrm{ij}}+\cdots+a_{p p} Y_{p, i j}
\end{aligned}
$$


with $P C_{1}$ as the first principal component, and $P C_{2}$ as the second principal component. 4. Determine the number of components that can be formed based on the variance percentage criteria.

The number of principal components used in cluster analysis should have a cumulative percentage of at least $80 \%$ variance (Rencher 2001). The component score, which will be used as input for the k-means cluster analysis will then be calculated. The component score obtained from $\mathrm{m}$ principal components (where $m<p$ ) will be used in the k-means cluster analysis as a substitute for the original variable data values. The principal component analysis yields component score obtained from the multiplication of the original data with the eigen values (Johnson \& Wichern 2007).

Furthermore, the selection of the optimal number of the cluster can be determined by the following methods (Charrad et al. 2014; Maheswari 2019):

Within Sum of Square (WSS) Method

The steps for the WSS method are as follows: 1 . Determine the cluster using the K-Means algorithm with different $k$ values. 2. Determine variance withincluster sum of square $V_{w}$ for each $k$ with the following formula:

$$
V_{w}=\frac{1}{N-k} \sum_{i=1}^{k}\left(n_{i}-1\right) V_{i}^{2}
$$

where $N$ is the number of objects, $k$ is the number of clusters, $n_{i}$ is the number of members in $i$ - th group, and
$V^{2}$ is the variance of the $i$ - $t$ th group. 3. Plot the WSS graph for different $k$. 4. The elbow in the WSS plot indicates the optimal number of the cluster.

\section{Silhouette Method}

The steps for the Silhouette method are as follows: 1 . Determine the cluster using the k-means algorithm with different $k$ values. 2. Determine the average silhouette for each $k$ with the following formula

$$
\text { Silhouette }=\frac{\sum_{i=1}^{n} \frac{b(i)-a(i)}{\max \{a(i), b(i)\}}}{n}, \text { Silhouette } \in[-1,1]
$$

where $a(i)=\frac{\sum_{j \in C_{i}, i \neq j} d_{i j}}{n_{i}-1}$, is the average dissimilarity of the $i$ - th object to all other items of the cluster $C_{i} ; b(i)=\min$ $\sum_{j \in C} d_{i j}$

$\frac{\sum_{k \in C_{k}}}{n_{k}}$, is the average discrepancy of the $i-t h$ object to all other objects of cluster $C_{k}$. 3. Plot the Silhouette graph for different $k$. 4. The number of clusters having a maximum average silhouette width is the optimal number of the group.

The procedure for dynamic dependency modeling between rainfall and crop production and the potential crop growth clustering are provided in the following flowchart.

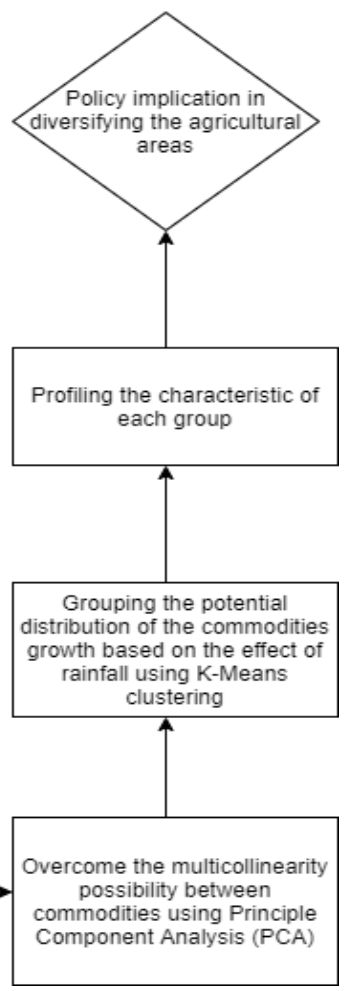




\section{RESULTS AND DISCUSSION}

The data in this study consists of the average monthly rainfall in one year and the annual food crop production in 34 provinces in Indonesia for the period of 1970 to 2017. We gathered the data from the official website of the BPS-Statistics Indonesia and the Indonesian Ministry of Agriculture (Kementerian Pertanian Indonesia). There are 9 types of food crop production: paddy, dryland paddy, wet rice field, maize, mung beans, peanuts, soybeans, sweet potatoes, and cassava. Table 1 provides the descriptive statistics of the rainfall data.

TABLE 1. Descriptive statistics of the average monthly rainfall data in a year in Indonesia from 1970 to 2017

\begin{tabular}{ccccc}
\hline Variable & Min & Max & Mean & Standard deviation \\
\hline $\begin{array}{l}\text { Rainfall data } \\
\text { (mm } \text { (month) }\end{array}$ & 182.99 & 300.45 & 239.88 & 24.24 \\
\hline
\end{tabular}

Table 1 shows that the minimum and maximum value of the annual monthly average rainfall in Indonesia was $182.99 \mathrm{~mm} / \mathrm{month}$ (occurring in 1997) and $300.45 \mathrm{~mm} /$ month (taking place in 2010), respectively, in the period of 1970 to 2017. Also, the mean of the annual average monthly rainfall was $239.88 \mathrm{~mm} / \mathrm{month}$, with a standard deviation of $24.24 \mathrm{~mm} / \mathrm{month}$. There are three categories for the amount of the average monthly rainfall, i.e., less than $60 \mathrm{~mm}$, between $60-100 \mathrm{~mm}$, and greater than 100 $\mathrm{mm}$, which are respectively categorized as dry month, moist month, and wet month. The average monthly rainfall in one year in Indonesia falls in the wet category based on these categorizations. It indicates that Indonesia has reasonably high rainfall, affecting plant growth either positively (meeting the plant's needs appropriately) or negatively (damaging plants if the amount is excessive), especially food crops. Furthermore, Figure 1 provides the rainfall data and the trend of food crop production in Indonesia from 1970 to 2017.

Based on Figure 1, the annual average monthly rainfall in Indonesia fluctuates around $200-300 \mathrm{~mm} /$ month with no significant increase or decrease. However, the production of food crops increased from year to year. Paddy experienced the highest growth rate, followed by the wet rice field and maize. Production of paddy and wet rice field rose from 19.3 million tons in 1970 to 81.1 million tons in 2017, and from 17.7 million tons in 1970 to 77.3 million tons in 2017 . Whereas, production of maize increased from 2.8 million tons in 1970 to 28.9 million tons in 2017. The data indicates that paddy and wet rice fields are the primary food crops commodities in Indonesia. The optimal monthly rainfall for paddy cultivation is around $200 \mathrm{~mm}$, with minimum rainfall of $115 \mathrm{~mm}$ (Chand 2020). Nevertheless, paddy production witnessed an increasing trend, although there were some significant decreases starting from 2000 until around 2005. The increasing trend occurred when the average rainfall is considered to be in the optimal range, thereby indicating a relationship between rainfall and paddy which may not be linear. This situation may also occur to other commodities. Therefore, we will investigate the dependency, particularly the dynamic dependency between rainfall and commodities production. Furthermore, Figure 2 provides the nine food crop production descriptive statistics in 34 provinces in Indonesia.

Figure 2 presents the maximum, mean, and minimum value of the 9 Indonesian food crop productions for each province from 1970 to 2017 and denotes that the major food crops planted in almost the entire regions were paddy, wet rice field, maize, and cassava (Supplementary file). The province with the highest paddy production was Jawa Timur, with the maximum value of 13.6 million tons, the mean value of 8.2 million tons, and the minimum value of 3.4 million tons. Jawa Timur also served as the province with the highest production of wet rice field and maize. The wet rice field's maximum and minimum output 

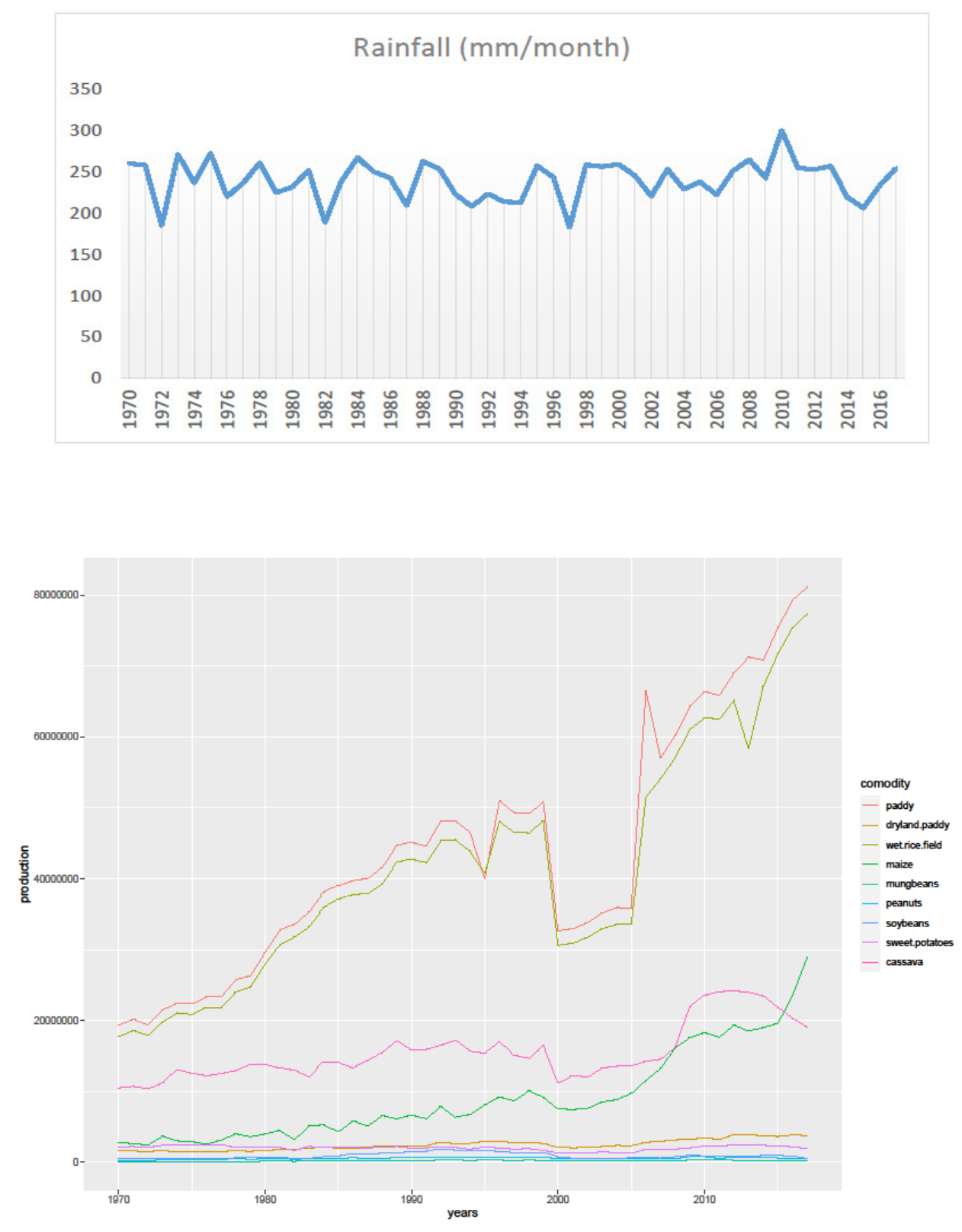

FIGURE 1. Rainfall data and the trend of food crops production in Indonesia from 1970 to 2017

were 12.9 million tons and 3.3 million tons, respectively, with the mean value of 7.9 million tons achieved. The maximum and minimum production of maize was 6.3 million tons and 0.96 million tons, respectively. The highest production of cassava was contributed by Kepulauan Riau, with the value of 9.1 million tons. The production of other commodities was relatively much smaller compared to the three commodities. 
The crop production was found to vary by province. Based on the rainfall fluctuation provided in Figure 1 and the crop production supplied in Figures 1 and 2, we assume that rainfall leads to different effects on the production of each commodity. To confirm this assumption, we shall conduct a dependency test between rainfall and food crop production.
Following the procedures explained in the previous section regarding identifying the structure of dependence using the dynamic copula model, we first conducted the modeling for the marginal variables, namely rainfall, and the nine food crop productions, while several ARIMA models for food crop production would be constructed. To get the ARIMA model for rainfall data, the first step we took was to determine whether differencing the data
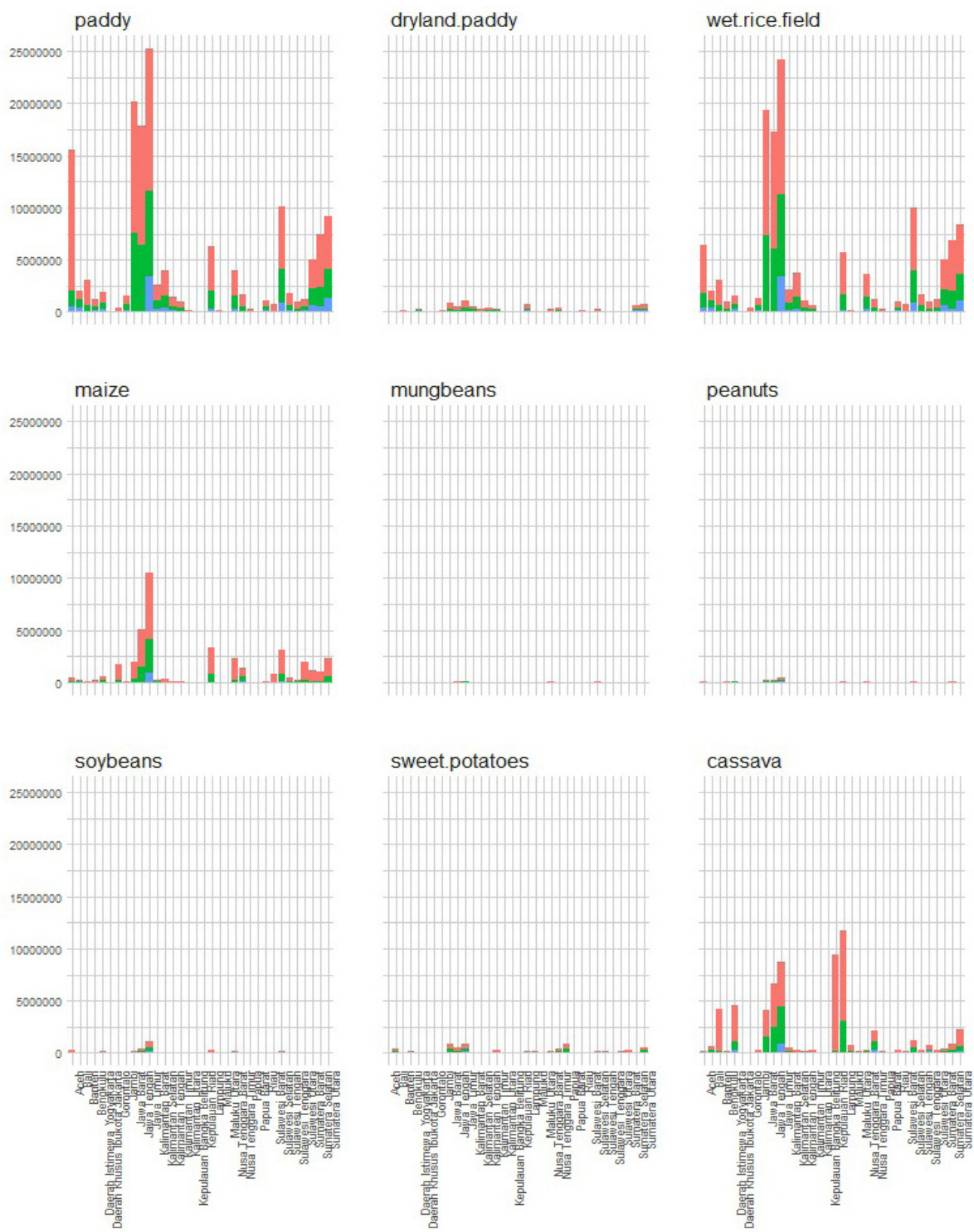

value

maximum

mean

minimum

FIGURE 2. Descriptive statistics of food crops production for each province in Indonesia 
was required using the unit root test or not. In our analysis, we used the Augmented Dickey-Fuller (ADF) test. In ADF test, the null hypothesis is the data which has a unit root, indicating that the data is non-stationary. The ADF test result shows that the value of the ADF-test is -3.2622 , with a $p$-value of 0.08845 . Because the $p$-value is greater than the significant level of 0.05 , the null hypothesis is not rejected so that the data is non-stationary. Thus, based on our ADF test results, we conclude the need to differentiate the data to obtain the stationarity property. In the next step, we combined various autoregressive and moving average orders to get the best ARIMA model based on the smallest AIC value. We used the HyndmanKhandakar algorithm to conduct this marginal modeling (Hyndman \& Athanasopoulos 2018). Table 2 presents the ARIMA model's comparison with several combinations of orders of autoregressive and moving average and the corresponding AIC values.

TABLE 2. ARIMA model selection for rainfall data

\begin{tabular}{cc}
\hline Model & AIC \\
\hline ARIMA $(2,1,2)$ & 445.29 \\
ARIMA $(2,1,1)$ & 444.71 \\
ARIMA $(1,1,2)$ & 444.77 \\
ARIMA $(1,1,1)$ & 458.83 \\
ARIMA $(1,1,0)$ & 442.86 \\
ARIMA $(0,1,1)$ & $440.92 *$ \\
\hline
\end{tabular}

*the best ARIMA model

Table 2 denotes that the best ARIMA model for rainfall data is ARIMA $(0,1,1)$ as it has the smallest AIC value. Using similar procedures, we obtain the best order for ARIMA modeling for the commodities production provided in Table S.2 of the Supplementary File. All of the crop production models are ARIMA because, based on the analysis, the data are non-stationary so that the suitable model for each commodity is ARIMA.

In the next step, we identify the dependency of each commodity with the rainfall using Kendall's tau correlation which is shown in Figure 3.

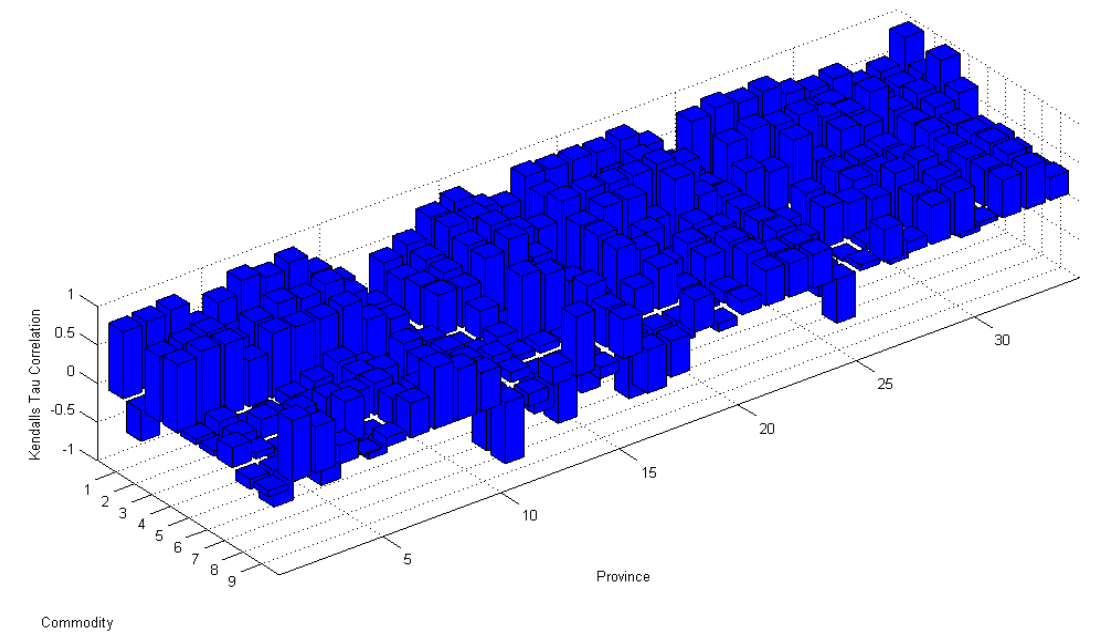

FIGURE 3. Kendall's Tau correlation of each commodity in each province 
Based on Figure 3, the Kendall's Tau correlation between rainfall and commodities in each province is quite significant, either negative or positive. Thus, we could use copula model to model the structure of dependence between rainfall and commodities in each province. Furthermore, we selected and estimated the parameters of the dynamic copula models using (2) - (8). The best copula model which was determined based on the smallest AIC value is provided in Table S.3 in Supplementary File. Generally, the best copula model, which most dominantly illustrates the dependencies between rainfall and food crop commodities in 34 provinces, is the dynamic Gaussian copula $(47.39 \%)$, followed by the dynamic SJC (35.95\%), dynamic Clayton (14.05\%), and dynamic Gumbel copula (1.96\%). The other $0.65 \%$ is from the static Gaussian copula. The parameter estimates for the dynamic copula for each food crop at individual province is provided in Table S.3 in the Supplementary File. Using (7), the parameter estimates $\hat{\omega}, \hat{\beta}$, and $\hat{\alpha}$ are combined to form the dynamic parameter $\Omega_{t}$ for each copula. Unlike the static copula parameter, which remains constant throughout the observations, the dynamic parameter always changes every time. This dynamic behavior is more flexible than static behavior because it describes the possible change in the dependency of rainfall on commodities production at every time, which can cause the change in the crop production due to rainfall influence. Therefore, the dynamic copula is assumed to better represent the behavior of dependence on time series data or data involving information in the past. Figure 4 shows the comparison between dynamic and static Gaussian copula parameters for paddy commodities in DKI Jakarta.

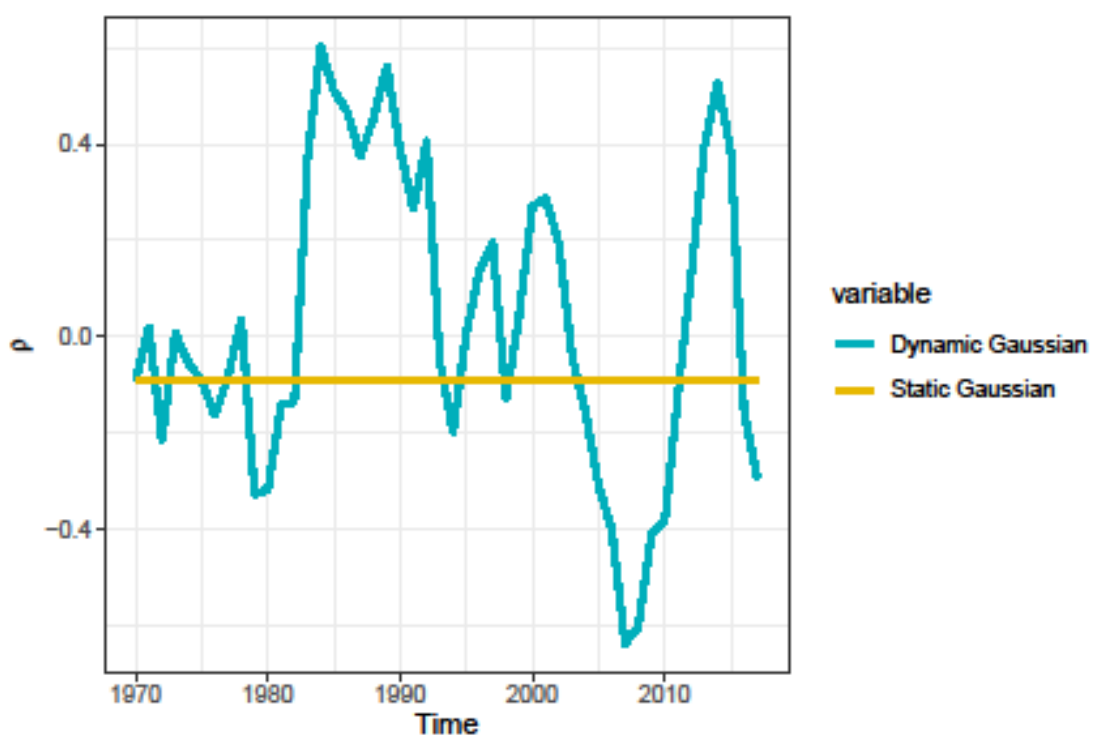

FIGURE 4. Comparison of the dynamic and static gaussian copula parameter

Figure 4 shows that the dynamic parameter differs from the static parameter in terms of temporal dependence. The static copula is obtained by maximizing the log-likelihood function in (8) with a constant value of parameter, i.e. the parameter $\Omega$ do not follow (7) but is of single value. While static copula indicates parameters with the same value across time, dynamic copula denotes different behavior, i.e. the parameters always change across time. This behavior highlights the dynamic nature of dependence. Using the parameter estimates provided in Table S.3, the predicted values of the food crop productions based on dynamic copula models compared to the actual data are obtained and provided in Figure 5. The predictions' accuracy is measured using the mean absolute percentage error (MAPE), which is provided in Table 3. 

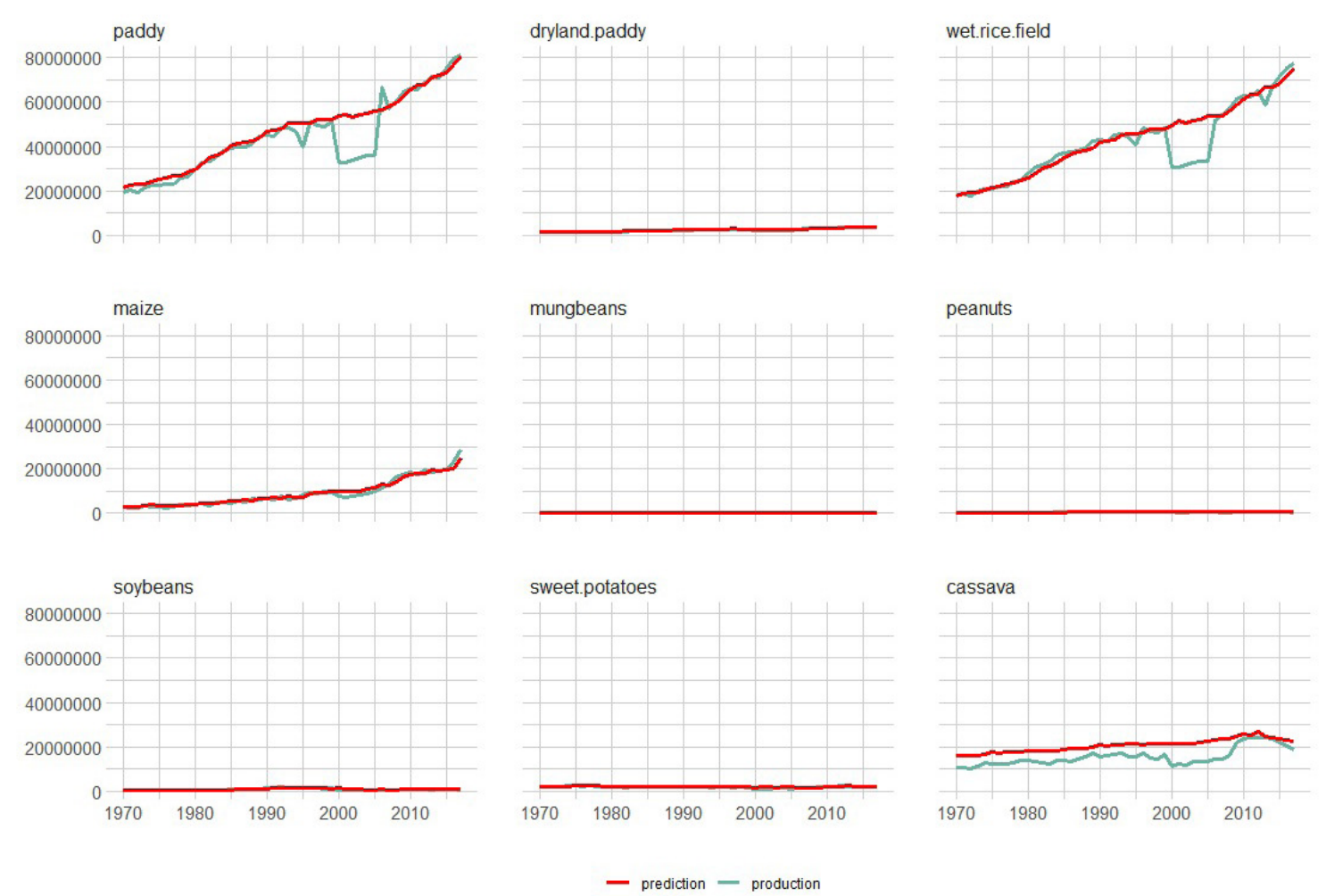

- prediction - production

FIGURE 5. Prediction of the trend of food crops production in Indonesia from 1970 to 2017

TABLE 3. MAPE of the dynamic copula-based prediction of total food crop production

\begin{tabular}{lc}
\hline \multicolumn{1}{c}{ Commodity } & MAPE \\
\hline Paddy & $11.92 \%$ \\
Dryland paddy & $5.79 \%$ \\
Wet rice field & $10.81 \%$ \\
Maize & $13.59 \%$ \\
Mung beans & $18.36 \%$ \\
Soybeans & $14.87 \%$ \\
Peanuts & $15.54 \%$ \\
Sweet potatoes & $10.45 \%$ \\
Cassava & $36.25 \%$ \\
\hline
\end{tabular}


Red and grey line in Figure 5 indicate the prediction and the actual value of the crop production based on the best dynamic copula model selected for each commodity. Figure 5 depicts that the prediction using dynamic copula model gives a relatively good results except some jumps on the prediction of the paddy and wet rice field. However, small value of the MAPEs, which are less than 20\% except for cassava prediction may provide an adequate justification on the validity of this model.

The results of the prediction of food crops produced using the dynamic copula modeling, in a more specific form; per province and per commodity, are used to determine the potential distribution of food crop commodities production in all regions in Indonesia. We tried to obtain the characteristic of food crops yield by grouping the provinces with higher food crop production and identify areas with potential commodities using k-means clustering. Following the procedures explained in the previous section, we first checked the Bartlett test's multicollinearity assumption. First, we set the null hypothesis $H_{0}$, which stated that there is no correlation between all commodities variables, and the alternative hypothesis $H_{1}$, which said that there are at least two correlated variables. Mathematically, the hypothesis testing for the multicollinearity checking is as follows

$$
\begin{aligned}
& H_{0}: \rho_{11}=\rho_{12}=\ldots=\rho_{99}=0 \\
& H_{1}: \exists i k, \rho_{i k} \neq 0, i=1,2, \ldots, 9, k=1,2, \ldots, 9, \text { for at least one } i \neq k
\end{aligned}
$$

Using $\alpha=0.05$, we obtained $p$-value of $2.2 \times 10^{-16}$ which means that the null hypothesis is rejected. Therefore, there are at least two correlated variables. Given the multicollinearity in the research variables, the cluster analysis cannot be done. To overcome the multicollinearity issue, we conducted a principal component analysis (PCA) with the results provided in Table 4.

TABLE 4. Eigen value of principal component

\begin{tabular}{cccc}
\hline Dimension & $\begin{array}{l}\text { Eigen } \\
\text { value }\end{array}$ & $\begin{array}{c}\text { Percentage } \\
\text { of variance }\end{array}$ & $\begin{array}{c}\text { Cumulative percentage } \\
\text { of variance }\end{array}$ \\
\hline 1 & 6.85 & 76.11 & 76.11 \\
2 & 0.81 & 9.11 & 85.22 \\
4 & 0.56 & 6.29 & 91.51 \\
5 & 0.38 & 4.32 & 95.83 \\
6 & 0.20 & 2.22 & 98.05 \\
7 & 0.10 & 1.14 & 99.20 \\
8 & 0.04 & 0.48 & 99.68 \\
9 & 0.02 & 0.28 & 99.97 \\
\hline
\end{tabular}


Based on Table 4 with the cumulative percentage of variance more significant than $80 \%$ of the data diversity, we obtained that the best score values to be used in the cluster analysis is from $P C_{1}$ and $P C_{2}$. Moreover, the recommended optimal number of two clusters is also based on the WSS and Silhouette methods. Figure 6(a) and 6(b) shows that the graph has a bend when $k=$ 2 and reach the peak when $k=2$, for WSS and Silhouette methods, respectively, indicating that the number of the optimum cluster suggested by both methods is two.

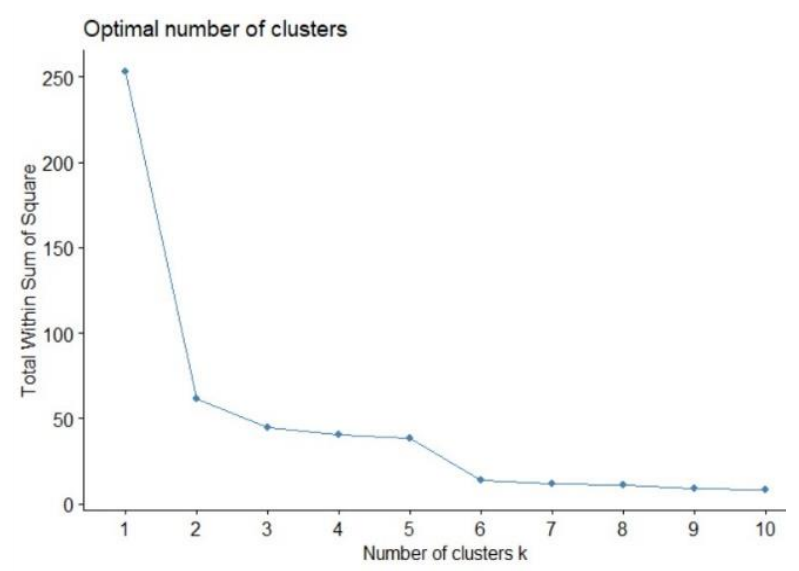

(a) WSS Method

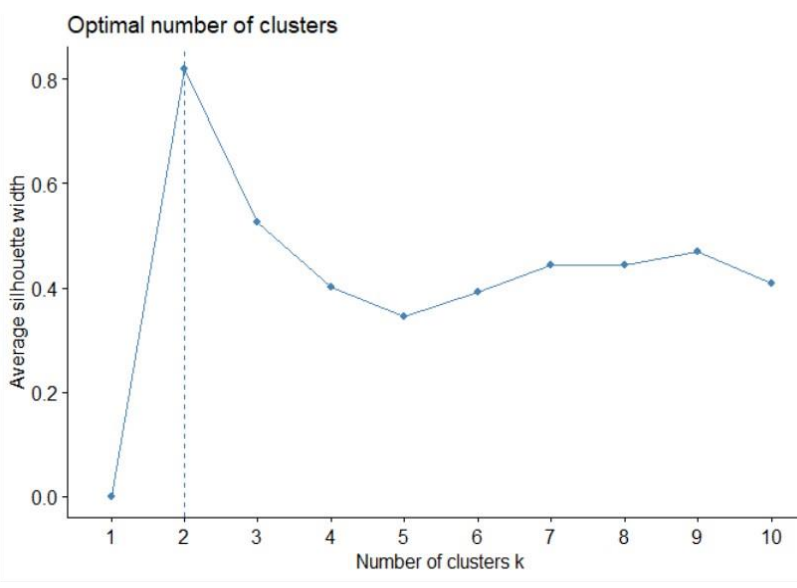

(b) Silhouette Method

FIGURE 6. Selection of the optimal number of clusters

By following the k-means clustering algorithm presented in the previous section, we obtained 2 clusters with three provinces in the first cluster and 31 provinces in the second cluster, summarized in Table 5.

TABLE 5. Member of each cluster

\begin{tabular}{cl}
\hline Cluster & \multicolumn{1}{c}{ The member of cluster } \\
\hline 1 & Jawa Timur, Jawa Tengah, Jawa Barat \\
2 & Aceh, Sumatera Utara, Sumatera Barat, Riau, Jambi, Sumatera Selatan, Bengkulu, Lampung, \\
& Kepulauan Riau, Kepulauan Bangka Belitung, DKI Jakarta, D.I. Yogyakarta, Banten, Bali, NTB, NTT, \\
& Kalimantan Barat, Kalimantan Tengah, Kalimantan Selatan, Kalimantan Timur, Kalimantan Utara, \\
& Sulawesi Utara, Sulawesi Tengah, Sulawesi Selatan, Sulawesi Tenggara, Sulawesi Barat, Gorontalo, \\
& Maluku, Maluku Utara, Papua Barat, Papua
\end{tabular}


Cluster 1 in Table 5 consists of provinces with higher average production for all commodities compared to the regions in group 2. It could be due to reliable and suitable natural factors and human resources in the three provinces in cluster 1, i.e. Jawa Timur, Jawa Tengah, and Jawa Barat. On the other hand, there needs to be a special attention to the regions in group 2 related to food products' level to achieve equal distribution of food security in
Indonesia. In particular, Table 6 provides the provinces with potential commodities, where the production obtained from dynamic copula model for each entity tends to be high. The potential commodity provided in Table 6 is obtained by profiling the province which has large production in particular commodity. Meanwhile, the highest commodity production in each province is presented in Table 7.

TABLE 6. Provinces with potential commodity

\begin{tabular}{ll}
\hline Province & \multicolumn{1}{c}{ Commodity } \\
\hline Jawa Timur & Maize, Mung beans, Peanuts, Soybeans, Paddy, Dryland Paddy \\
Jawa Barat & Wet Rice Field, Sweet Potatoes \\
Kepulauan Riau & Cassava \\
\hline
\end{tabular}

TABLE 7. The highest commodity production in each province

\begin{tabular}{ll}
\hline Commodity & \multicolumn{1}{c}{ Province } \\
\hline Paddy & $\begin{array}{l}\text { Aceh, Sumatera Utara, Sumatera Barat, Riau, Jambi, Sumatera } \\
\text { Selatan, Bengkulu, Kepulauan Bangka Belitung, DKI Jakarta, Jawa } \\
\text { Barat, Jawa Tengah, Jawa Timur, Banten, Bali, Nusa Tenggara Barat, } \\
\text { Kalimantan Barat, Kalimantan Tengah, Kalimantan Timur, Kalimantan } \\
\text { Selatan, Sulawesi Utara, Sulawesi Tengah, Sulawesi Selatan, Sulawesi } \\
\text { Tenggara, Gorontalo, Sulawesi Barat }\end{array}$ \\
& $\begin{array}{l}\text { Lampung, Kepulauan Riau, D.I. Yogyakarta, Nusa Tenggara Timur, } \\
\text { Kalimantan Utara, Maluku, Maluku Utara, Papua Barat }\end{array}$ \\
& Papua \\
\hline
\end{tabular}

The results provided in Tables 6 and 7 suggest the following diversification. First, almost all provinces in Indonesia, except areas of Maluku and Papua, can optimize paddy planting. The only way to optimize food crop production in these two regions is by cultivating cassava and sweet potatoes. Other food crops with wider range of distribution throughout the provinces are particularly dryland paddy, maize, mung beans, peanuts, and soybeans, which is best to be cultivated in Jawa Timur, while wet rice field reaps the best yield in Jawa Barat. 


\section{CONCLUSION}

We have modeled rainfall's temporal effect on the food crop productions using dynamic copula and grouped the modeling result of the potential commodity production using k-means clustering. We obtained that dynamic copula can capture the temporal dependence between rainfall and food crop production in each province in Indonesia. The clustering result of the prediction of food crop production, which is influenced by the rainfall, suggests that we diversify the food crops planting so that each province can optimize their planting area. The results show that the best food crop to cultivate in almost all provinces in Sumatera, Jawa, Kalimantan, Sulawesi, Bali, and Nusa Tenggara are paddy. Meanwhile, the best area to grow cassava and sweet potatoes, respectively, are the areas of Maluku and Papua.

\section{ACKNOWLEDGEMENTS}

The authors would like to thank the Directorate of Research and Community Services (DPPM) of Universitas Islam Indonesia for providing the financial support for this research through Hibah Penelitian Berorientasi Luaran 2019 No. 011/Dir/DPPM/70/Pen. Unggulan/PI/IV/2019.

\section{REFERENCES}

Adimassu, Z., Kessler, A. \& Stroosnijder, L. 2014. Farmers' strategies to perceived trends of rainfall and crop productivity in the Central Rift Valley of Ethiopia. Environmental Development 11: 123-140.

Agusta, Y. 2007. K-Means - Penerapan, permasalahan dan metode terkait. Jurnal Sistem dan Informatika 3: 47-60.

Alidoost, F., Su, Z. \& Stein, A. 2019. Evaluating the effects of climate extremes on crop yield, production and price using multivariate distributions: A new copula application. Weather and Climate Extremes 26: 100227.

Antwi-Agyei, P., Fraser, E.D., Dougill, A.J. Stringer, L.C. \& Simelton, E. 2012. Mapping the vulnerability of crop production to drought in Ghana using rainfall, yield and socioeconomic data. Applied Geography 32(2): 324-334.

Ausin, M.C. \& Lopes, H.F. 2010. Time-varying joint distribution through copulas. Computational Statistics and Data Analysis 54(11): 2383-2399.

Bandara, J.S. \& Cai, Y. 2014. The impact of climate change on food crop productivity, food prices, and food security in South Asia. Economic Analysis and Policy 44(4): 451-465.
Bezabih, M. \& Di Falco, S. 2012. Rainfall variability and food crop portfolio choice: Evidence from Ethiopia. Food Security 4(4): 557-567.

Chand, S. 2020. Cultivation of Rice: Suitable Conditions Required for the Cultivation of Rice (6 Conditions). https:// www.yourarticlelibrary.com/cultivation/cultivation-ofrice-suitable-conditions-required-for-the-cultivation-ofrice-6-conditions/25491\#: :text=Rainfall\%3A, water\%20 than $\% 20$ any $\% 20$ other $\% 20$ crop. \& text $=$ Although $\% 20$ the $\% 20$ regions $\% 20$ are $\% 20$ having,weeks $\% 20$ of $\% 20$ the $\% 20$ growing\%20period. Accessed on October 20, 2020.

Charrad, M., Ghazzali, N., Boiteau, V. \& Niknafs, A. 2014. NbClust: An R package for determining the relevant number of clusters in a data set. Journal of Statistical Software 61(6): 1-36.

Cong, R.G. \& Brady, M. 2012. The interdependence between rainfall and temperature: Copula analyses. The Scientific World Journal 2012: Article ID. 405675.

Dash, P., Nayak, M. \& Das, G.P. 2014. Principal component analysis using singular value decomposition for image compression. International Journal of Computer Applications 93(9): 21-27. https://doi.org/10.5120/162435795.

Han, J., Kamber, M. \& Pei, J. 2012. Data Mining Concepts and Techniques. Massachusetts: Morgan Kaufmann Publishers.

Hyndman, R.J. \& Athanasopoulos, G. 2018. Forecasting: Principles and Practice. 2nd ed. OTexts: Melbourne.

Haraty, R.A., Dimishkieh, M. \& Masud, M. 2015. An enhanced k-Means clustering algorithm for pattern discovery in healthcare data. International Journal of Distributed Sensor Networks 11(6).

James, G., Witten, D., Hastie, T. \& Tibshirani, R. 2013. An Introduction to Statistical Learning with Applications in R. New York: Springer.

Johnson, R.A. \& Wichern, D.W. 2007. Applied Multivariate Statistical Analysis. 6th ed. New Jersey: Pearson Prentice Hall.

Jondeau, E. \& Rockinger, M. 2006. The Copula-GARCH model of conditional dependencies: An international stock market application. Journal of International Money and Finance 25(5): 827-853.

Juaeni, I. 2014. Impact of principal component analysis (PCA) implementation on rainfall clustering over Java, Bali, and Lombok Islands. Jurnal Sains Dirgantara 11(2): 97-108.

Li, Y., Gu, W., Cui, W., Chang, Z. \& Xu, Y. 2015. Exploration of copula function use in crop meteorological drought risk analysis: A case study of winter wheat in Beijing, China. Natural Hazards 77(2): 1289-1303.

Maheswari, K. 2019. Finding best possible number of clusters using k-means algorithm. International Journal of Engineering and Advanced Technology 9(1S4). 
Manner, H. \& Reznikova, O. 2012. A survey on time-varying copulas: Specification, simulations, and application. Econometric Reviews 31(6): 654-687.

Ministry of Agriculture. 2018. Data Lima Tahun Terakhir. pertanian.go.id Accessed on October 20, 2020.

Nguyen-Huy, T., Deo, R.C., Mushtaq, S., An-Vo, D.A. \& Khan, S. 2018. Modeling the joint influence of multiple synoptic-scale, climate mode indices on Australian wheat yield using a vine copula-based approach. European Journal of Agronomy 98(May): 65-81.

Patton, A.J. 2006. Modelling asymmetric exchange rate dependence. International Economic Review 47(2): 527556.

Rencher, A.C. 2001. Method of Multivariate Analysis. 2nd ed. New York: A Wiley-Interscience Publication.

Ribeiro, A.F., Russo, A., Gouveia, C.M. \& Pascoa, P. 2019. Copula-based agricultural drought risk of rainfed cropping systems. Agricultural Water Management 223: 105689.

Sklar, A. 1959. Distribution functions of $\mathrm{n}$ dimensions and margins. Publications of the Institute of Statistics of the University of Paris 8: 229-231.

Tao, F., Yokozawa, M. \& Zhang, Z. 2009. Modelling the impacts of weather and climate variability on crop productivity over a large area: A new process-based model development, optimization, and uncertainties analysis. Agricultural and Forest Meteorology 149(5): 831-850.

Team of SUTAS2018. 2018. Result of Inter-Censal Agricultural Survey 2018. Jakarta: BPS-Statistics, Indonesia.

Turvey, C.G. 1991. Regional and farm-level risk analyses with the single-index model. Northeastern Journal of Agricultural and Resource Economics 20(2): 181-188.
Vogel, E., Donat, M.G., Alexander, L.V., Meinshausen, M., Ray, D.K., Karoly, D., Meinshausen, N. \& Frieler, K. 2019. The effects of climate extremes on global agricultural yields. Environmental Research Letters 14: 054010.

Xu, W., Filler, G., Odening, M. \& Okhrin, O. 2010. On the systemic nature of weather risk. Agricultural Finance Review 70(2): $267-284$

Atina Ahdika*, Mujiati Dwi Kartikasari \& Sekti Kartika Dini Department of Statistics

Faculty of Mathematics and Natural Sciences

Universitas Islam Indonesia, Yogyakarta

Indonesia

Intan Ramadhani

Alumnus of Department of Statistics

Faculty of Mathematics and Natural Sciences

Universitas Islam Indonesia, Yogyakarta

Indonesia

Intan Ramadhani

PT Sigma Cipta Caraka (TelkomSigma), Tangerang Indonesia

*Corresponding author; email: atina.a@uii.ac.id

Received: 20 July 2020

Accepted: 15 January 2021

TABLE S.1. ARIMA models for commodities production

\begin{tabular}{|c|c|c|c|c|c|c|c|c|c|}
\hline Province & Paddy & Dryland paddy & Wet rice field & Maize & Mungbeans & Peanuts & Soybeans & Sweet potatoes & Cassava \\
\hline Aceh & $\operatorname{ARIMA}(0,1,1)$ & $\operatorname{ARIMA}(0,1,1)$ & $\operatorname{ARIMA}(0,1,1)$ & $\operatorname{ARIMA}(0,2,1)$ & $\operatorname{ARIMA}(1,1,0)$ & $\operatorname{ARIMA}(1,0,3)$ & $\operatorname{ARIMA}(1,1,0)$ & $\operatorname{ARIMA}(0,2,1)$ & $\operatorname{ARIMA}(0,1,1)$ \\
\hline $\begin{array}{l}\text { Sumatera } \\
\text { Utara }\end{array}$ & $\operatorname{ARIMA}(1,1,0)$ & $\operatorname{ARIMA}(2,0,0)$ & $\operatorname{ARIMA}(0,2,1)$ & $\operatorname{ARIMA}(0,2,1)$ & $\operatorname{ARIMA}(1,1,1)$ & $\operatorname{ARIMA}(0,2,1)$ & $\operatorname{ARIMA}(1,0,1)$ & $\operatorname{ARIMA}(0,2,1)$ & $\operatorname{ARIMA}(0,3,1)$ \\
\hline $\begin{array}{l}\text { Sumatera } \\
\text { Barat }\end{array}$ & $\operatorname{ARIMA}(3,1,0)$ & $\operatorname{ARIMA}(0,2,1)$ & $\operatorname{ARIMA}(3,1,0)$ & $\operatorname{ARIMA}(0,2,1)$ & $\operatorname{ARIMA}(0,2,1)$ & $\operatorname{ARIMA}(0,2,1)$ & $\operatorname{ARIMA}(0,2,1)$ & $\operatorname{ARIMA}(0,2,1)$ & $\operatorname{ARIMA}(0,2,1)$ \\
\hline Riau & $\operatorname{ARIMA}(0,2,1)$ & $\operatorname{ARIMA}(0,1,1)$ & $\operatorname{ARIMA}(0,1,1)$ & $\operatorname{ARIMA}(0,1,1)$ & $\operatorname{ARIMA}(1,0,2)$ & $\operatorname{ARIMA}(0,1,1)$ & $\operatorname{ARIMA}(1,1,0)$ & $\operatorname{ARIMA}(0,1,1)$ & $\operatorname{ARIMA}(0,2,1)$ \\
\hline Jambi & $\operatorname{ARIMA}(0,1,1)$ & $\operatorname{ARIMA}(0,2,1)$ & $\operatorname{ARIMA}(0,1,1)$ & $\operatorname{ARIMA}(1,2,0)$ & $\operatorname{ARIMA}(2,0,0)$ & $\operatorname{ARIMA}(2,1,2)$ & $\operatorname{ARIMA}(0,2,1)$ & $\operatorname{ARIMA}(0,2,1)$ & $\operatorname{ARIMA}(1,0,1)$ \\
\hline $\begin{array}{l}\text { Sumatera } \\
\text { Selatan }\end{array}$ & $\operatorname{ARIMA}(0,2,2)$ & $\operatorname{ARIMA}(0,1,1)$ & $\operatorname{ARIMA}(0,2,1)$ & $\operatorname{ARIMA}(1,2,0)$ & $\operatorname{ARIMA}(1,1,1)$ & $\operatorname{ARIMA}(1,0,0)$ & $\operatorname{ARIMA}(0,2,1)$ & $\operatorname{ARIMA}(0,1,3)$ & $\operatorname{ARIMA}(1,0,0)$ \\
\hline Bengkulu & $\operatorname{ARIMA}(0,2,1)$ & $\operatorname{ARIMA}(1,0,0)$ & $\operatorname{ARIMA}(0,1,1)$ & $\operatorname{ARIMA}(0,1,3)$ & $\operatorname{ARIMA}(0,2,1)$ & $\operatorname{ARIMA}(0,1,1)$ & $\operatorname{ARIMA}(0,2,1)$ & $\operatorname{ARIMA}(0,2,1)$ & $\operatorname{ARIMA}(0,1,3)$ \\
\hline Lampung & $\operatorname{ARIMA}(2,2,0)$ & $\operatorname{ARIMA}(0,2,1)$ & $\operatorname{ARIMA}(1,2,2)$ & $\operatorname{ARIMA}(0,1,1)$ & $\operatorname{ARIMA}(2,1,2)$ & $\operatorname{ARIMA}(0,1,1)$ & $\operatorname{ARIMA}(0,2,1)$ & $\operatorname{ARIMA}(1,1,0)$ & $\operatorname{ARIMA}(0,1,1)$ \\
\hline $\begin{array}{l}\text { Kep. } \\
\text { Bangka } \\
\text { Belitung }\end{array}$ & $\operatorname{ARIMA}(4,1,0)$ & $\operatorname{ARIMA}(0,1,1)$ & $\operatorname{ARIMA}(3,1,0)$ & $\operatorname{ARIMA}(1,0,1)$ & $\operatorname{ARIMA}(0,1,1)$ & $\operatorname{ARIMA}(0,0,4)$ & $\operatorname{ARIMA}(0,1,1)$ & $\operatorname{ARIMA}(0,1,1)$ & $\operatorname{ARIMA}(0,2,1)$ \\
\hline Kep. Riau & $\operatorname{ARIMA}(2,0,1)$ & $\operatorname{ARIMA}(0,1,2)$ & $\operatorname{ARIMA}(2,0,1)$ & $\operatorname{ARIMA}(1,0,2)$ & $\operatorname{ARIMA}(1,0,1)$ & $\operatorname{ARIMA}(1,0,1)$ & $\operatorname{ARIMA}(2,0,2)$ & $\operatorname{ARIMA}(0,0,1)$ & $\operatorname{ARIMA}(0,1,1)$ \\
\hline
\end{tabular}




\begin{tabular}{|c|c|c|c|c|c|c|c|c|c|}
\hline Province & Paddy & Dryland paddy & Wet rice field & Maize & Mungbeans & Peanuts & Soybeans & Sweet potatoes & Cassava \\
\hline $\begin{array}{l}\text { DKI } \\
\text { Jakarta }\end{array}$ & $\operatorname{ARIMA}(0,2,1)$ & $\operatorname{ARIMA}(1,0,0)$ & $\operatorname{ARIMA}(0,2,1)$ & $\operatorname{ARIMA}(0,1,3)$ & $\operatorname{ARIMA}(0,1,1)$ & $\operatorname{ARIMA}(1,1,0)$ & $\operatorname{ARIMA}(0,1,1)$ & $\operatorname{ARIMA}(3,1,0)$ & $\operatorname{ARIMA}(0,2,1)$ \\
\hline Jawa Barat & $\operatorname{ARIMA}(0,1,1)$ & $\operatorname{ARIMA}(0,2,1)$ & $\operatorname{ARIMA}(0,1,1)$ & $\operatorname{ARIMA}(0,1,1)$ & $\operatorname{ARIMA}(0,1,1)$ & $\operatorname{ARIMA}(0,1,1)$ & $\operatorname{ARIMA}(1,1,1)$ & $\operatorname{ARIMA}(0,1,1)$ & $\operatorname{ARIMA}(1,0,0)$ \\
\hline $\begin{array}{l}\text { Jawa } \\
\text { Tengah }\end{array}$ & $\operatorname{ARIMA}(0,1,1)$ & $\operatorname{ARIMA}(1,1,1)$ & $\operatorname{ARIMA}(0,1,1)$ & $\operatorname{ARIMA}(0,1,1)$ & $\operatorname{ARIMA}(2,1,0)$ & $\operatorname{ARIMA}(0,1,2)$ & $\operatorname{ARIMA}(0,1,1)$ & $\operatorname{ARIMA}(0,1,1)$ & $\operatorname{ARIMA}(0,1,1)$ \\
\hline $\begin{array}{l}\text { DI } \\
\text { Yogyakarta }\end{array}$ & $\operatorname{ARIMA}(0,2,1)$ & $\operatorname{ARIMA}(0,1,1)$ & $\operatorname{ARIMA}(0,2,1)$ & $\operatorname{ARIMA}(0,1,2)$ & $\operatorname{ARIMA}(1,0,0)$ & $\operatorname{ARIMA}(0,1,1)$ & $\operatorname{ARIMA}(1,1,0)$ & $\operatorname{ARIMA}(4,1,1)$ & $\operatorname{ARIMA}(0,1,1)$ \\
\hline Jawa Timur & $\operatorname{ARIMA}(0,2,1)$ & $\operatorname{ARIMA}(3,2,0)$ & $\operatorname{ARIMA}(0,2,1)$ & $\operatorname{ARIMA}(0,1,1)$ & $\operatorname{ARIMA}(0,2,2)$ & $\operatorname{ARIMA}(0,1,1)$ & $\operatorname{ARIMA}(1,0,1)$ & $\operatorname{ARIMA}(1,1,1)$ & $\operatorname{ARIMA}(0,1,1)$ \\
\hline Banten & $\operatorname{ARIMA}(2,2,2)$ & $\operatorname{ARIMA}(2,1,2)$ & $\operatorname{ARIMA}(0,2,1)$ & $\operatorname{ARIMA}(0,3,1)$ & $\operatorname{ARIMA}(0,2,1)$ & $\operatorname{ARIMA}(0,0,1)$ & $\operatorname{ARIMA}(0,1,1)$ & $\operatorname{ARIMA}(1,2,1)$ & $\operatorname{ARIMA}(0,1,1)$ \\
\hline Bali & $\operatorname{ARIMA}(0,2,1)$ & $\operatorname{ARIMA}(1,1,1)$ & $\operatorname{ARIMA}(0,2,1)$ & $\operatorname{ARIMA}(1,1,1)$ & $\operatorname{ARIMA}(1,1,1)$ & $\operatorname{ARIMA}(0,2,1)$ & $\operatorname{ARIMA}(0,2,1)$ & $\operatorname{ARIMA}(0,2,1)$ & $\operatorname{ARIMA}(0,1,1)$ \\
\hline $\begin{array}{l}\text { Nusa } \\
\text { Tenggara } \\
\text { Barat }\end{array}$ & $\operatorname{ARIMA}(1,1,0)$ & $\operatorname{ARIMA}(0,2,1)$ & $\operatorname{ARIMA}(1,1,0)$ & $\operatorname{ARIMA}(1,2,0)$ & $\operatorname{ARIMA}(2,1,2)$ & $\operatorname{ARIMA}(0,2,1)$ & $\operatorname{ARIMA}(0,1,1)$ & $\operatorname{ARIMA}(0,1,1)$ & $\operatorname{ARIMA}(2,1,1)$ \\
\hline $\begin{array}{l}\text { Nusa } \\
\text { Tenggara } \\
\text { Timur }\end{array}$ & $\operatorname{ARIMA}(0,2,2)$ & $\operatorname{ARIMA}(0,1,1)$ & $\operatorname{ARIMA}(0,2,2)$ & $\operatorname{ARIMA}(0,1,1)$ & $\operatorname{ARIMA}(0,2,1)$ & $\operatorname{ARIMA}(0,2,1)$ & $\operatorname{ARIMA}(0,1,1)$ & $\operatorname{ARIMA}(0,1,1)$ & $\operatorname{ARIMA}(0,1,1)$ \\
\hline $\begin{array}{l}\text { Kalimantan } \\
\text { Barat }\end{array}$ & $\operatorname{ARIMA}(0,1,1)$ & $\operatorname{ARIMA}(0,1,1)$ & $\operatorname{ARIMA}(0,1,1)$ & $\operatorname{ARIMA}(1,1,0)$ & $\operatorname{ARIMA}(0,1,1)$ & $\operatorname{ARIMA}(0,2,1)$ & $\operatorname{ARIMA}(1,0,0)$ & $\operatorname{ARIMA}(1,0,1)$ & $\operatorname{ARIMA}(1,0,0)$ \\
\hline $\begin{array}{l}\text { Kalimantan } \\
\text { Tengah }\end{array}$ & $\operatorname{ARIMA}(2,1,2)$ & $\operatorname{ARIMA}(2,1,2)$ & $\operatorname{ARIMA}(2,1,1)$ & $\operatorname{ARIMA}(0,1,1)$ & $\operatorname{ARIMA}(0,1,1)$ & $\operatorname{ARIMA}(0,2,1)$ & $\operatorname{ARIMA}(0,1,1)$ & $\operatorname{ARIMA}(2,0,2)$ & $\operatorname{ARIMA}(1,0,0)$ \\
\hline $\begin{array}{l}\text { Kalimantan } \\
\text { Selatan }\end{array}$ & $\operatorname{ARIMA}(0,1,1)$ & $\operatorname{ARIMA}(0,1,1)$ & $\operatorname{ARIMA}(0,1,1)$ & $\operatorname{ARIMA}(1,2,0)$ & $\operatorname{ARIMA}(1,1,0)$ & $\operatorname{ARIMA}(0,2,1)$ & $\operatorname{ARIMA}(1,1,0)$ & ARIMA(1,1,1) & $\operatorname{ARIMA}(0,2,1)$ \\
\hline $\begin{array}{l}\text { Kalimantan } \\
\text { Timur }\end{array}$ & $\operatorname{ARIMA}(0,1,1)$ & $\operatorname{ARIMA}(0,1,1)$ & $\operatorname{ARIMA}(1,1,0)$ & $\operatorname{ARIMA}(1,1,0)$ & $\operatorname{ARIMA}(1,1,1)$ & $\operatorname{ARIMA}(0,1,1)$ & $\operatorname{ARIMA}(0,1,1)$ & ARIMA $(0,1,1)$ & $\operatorname{ARIMA}(0,3,1)$ \\
\hline $\begin{array}{l}\text { Kalimantan } \\
\text { Utara }\end{array}$ & $\operatorname{ARIMA}(0,3,1)$ & $\operatorname{ARIMA}(0,2,1)$ & $\operatorname{ARIMA}(0,1,2)$ & $\operatorname{ARIMA}(1,1,0)$ & $\operatorname{ARIMA}(2,0,1)$ & $\operatorname{ARIMA}(1,0,0)$ & $\operatorname{ARIMA}(0,1,1)$ & ARIMA $(0,1,1)$ & $\operatorname{ARIMA}(3,0,0)$ \\
\hline $\begin{array}{l}\text { Sulawesi } \\
\text { Utara }\end{array}$ & $\operatorname{ARIMA}(0,1,1)$ & $\operatorname{ARIMA}(1,0,0)$ & $\operatorname{ARIMA}(2,1,2)$ & ARIMA $(1,1,0)$ & $\operatorname{ARIMA}(1,0,0)$ & $\operatorname{ARIMA}(0,2,1)$ & $\operatorname{ARIMA}(1,0,0)$ & $\operatorname{ARIMA}(1,1,1)$ & $\operatorname{ARIMA}(0,2,1)$ \\
\hline $\begin{array}{l}\text { Sulawesi } \\
\text { Tengah }\end{array}$ & $\operatorname{ARIMA}(0,1,3)$ & $\operatorname{ARIMA}(1,1,1)$ & $\operatorname{ARIMA}(2,1,0)$ & $\operatorname{ARIMA}(1,2,0)$ & $\operatorname{ARIMA}(1,0,0)$ & $\operatorname{ARIMA}(0,1,1)$ & $\operatorname{ARIMA}(0,2,1)$ & ARIMA $(1,0,0)$ & $\operatorname{ARIMA}(1,0,0)$ \\
\hline $\begin{array}{l}\text { Sulawesi } \\
\text { Selatan }\end{array}$ & $\operatorname{ARIMA}(0,1,1)$ & $\operatorname{ARIMA}(1,1,1)$ & $\operatorname{ARIMA}(0,2,1)$ & $\operatorname{ARIMA}(1,1,1)$ & $\operatorname{ARIMA}(0,1,1)$ & $\operatorname{ARIMA}(1,0,1)$ & $\operatorname{ARIMA}(0,2,1)$ & $\operatorname{ARIMA}(0,0,1)$ & $\operatorname{ARIMA}(2,1,0)$ \\
\hline $\begin{array}{l}\text { Sulawesi } \\
\text { Tenggara }\end{array}$ & $\operatorname{ARIMA}(3,2,0)$ & $\operatorname{ARIMA}(1,0,0)$ & $\operatorname{ARIMA}(3,2,0)$ & $\operatorname{ARIMA}(0,1,1)$ & $\operatorname{ARIMA}(0,1,1)$ & $\operatorname{ARIMA}(1,2,0)$ & $\operatorname{ARIMA}(0,1,1)$ & $\operatorname{ARIMA}(0,1,1)$ & $\operatorname{ARIMA}(0,1,1)$ \\
\hline Gorontalo & $\operatorname{ARIMA}(1,2,1)$ & $\operatorname{ARIMA}(1,1,1)$ & $\operatorname{ARIMA}(1,2,1)$ & $\operatorname{ARIMA}(0,3,1)$ & $\operatorname{ARIMA}(1,0,1)$ & $\operatorname{ARIMA}(0,2,1)$ & $\operatorname{ARIMA}(0,2,1)$ & $\operatorname{ARIMA}(0,2,2)$ & $\operatorname{ARIMA}(0,1,1)$ \\
\hline $\begin{array}{l}\text { Sulawesi } \\
\text { Barat }\end{array}$ & $\operatorname{ARIMA}(0,2,1)$ & $\operatorname{ARIMA}(1,1,2)$ & $\operatorname{ARIMA}(0,2,1)$ & $\operatorname{ARIMA}(1,2,1)$ & $\operatorname{ARIMA}(2,0,0)$ & $\operatorname{ARIMA}(1,0,0)$ & $\operatorname{ARIMA}(4,1,0)$ & $\operatorname{ARIMA}(0,3,1)$ & $\operatorname{ARIMA}(0,1,1)$ \\
\hline Maluku & $\operatorname{ARIMA}(1,1,0)$ & $\operatorname{ARIMA}(0,1,1)$ & $\operatorname{ARIMA}(1,1,0)$ & $\operatorname{ARIMA}(2,0,0)$ & $\operatorname{ARIMA}(0,2,1)$ & $\operatorname{ARIMA}(0,1,1)$ & $\operatorname{ARIMA}(0,1,1)$ & ARIMA $(0,1,1)$ & $\operatorname{ARIMA}(1,0,1)$ \\
\hline $\begin{array}{l}\text { Maluku } \\
\text { Utara }\end{array}$ & $\operatorname{ARIMA}(2,2,0)$ & $\operatorname{ARIMA}(1,2,0)$ & $\operatorname{ARIMA}(2,1,2)$ & $\operatorname{ARIMA}(0,0,1)$ & $\operatorname{ARIMA}(2,1,1)$ & $\operatorname{ARIMA}(0,1,1)$ & $\operatorname{ARIMA}(0,3,1)$ & $\operatorname{ARIMA}(3,0,0)$ & $\operatorname{ARIMA}(0,0,1)$ \\
\hline Papua & $\operatorname{ARIMA}(1,1,1)$ & $\operatorname{ARIMA}(0,1,1)$ & $\operatorname{ARIMA}(0,1,1)$ & $\operatorname{ARIMA}(2,1,2)$ & $\operatorname{ARIMA}(0,2,1)$ & $\operatorname{ARIMA}(0,1,2)$ & $\operatorname{ARIMA}(1,1,1)$ & $\operatorname{ARIMA}(0,2,1)$ & $\operatorname{ARIMA}(0,1,3)$ \\
\hline $\begin{array}{l}\text { Papua } \\
\text { Barat }\end{array}$ & $\operatorname{ARIMA}(1,1,1)$ & $\operatorname{ARIMA}(0,2,1)$ & $\operatorname{ARIMA}(0,2,1)$ & $\operatorname{ARIMA}(3,1,1)$ & $\operatorname{ARIMA}(2,1,2)$ & $\operatorname{ARIMA}(0,1,1)$ & $\operatorname{ARIMA}(1,1,0)$ & $\operatorname{ARIMA}(0,1,1)$ & $\operatorname{ARIMA}(1,0,0)$ \\
\hline
\end{tabular}

TABLE S.2. The best copula selection criteria

\begin{tabular}{|c|c|c|c|c|c|c|c|c|c|c|}
\hline \multirow[b]{2}{*}{ Province } & \multirow[b]{2}{*}{ Copula } & \multicolumn{9}{|c|}{ AIC Commodities } \\
\hline & & Paddy & Dryland paddy & Wet rice field & Maize & Mungbeans & Soybeans & Peanuts & $\begin{array}{c}\text { Sweet } \\
\text { potatoes }\end{array}$ & Cassava \\
\hline \multirow{8}{*}{ Aceh } & Stat-Gaussian & $-0,16$ & $-0,03$ & 0,04 & $-0,09$ & $-3,60$ & $-1,98$ & $-1,44$ & $-0,59$ & $-2,40$ \\
\hline & Stat-Clayton & 0,04 & 0,04 & 0,03 & 0,04 & 0,05 & 0,04 & 0,04 & 0,04 & 0,05 \\
\hline & Stat-Gumbel & 1,69 & 0,08 & 1,00 & 1,52 & 3,77 & 2,93 & 2,72 & 2,08 & 3,53 \\
\hline & Stat-SJC & 0,29 & $-0,22$ & 0,27 & 0,27 & 0,92 & 0,90 & 0,85 & 0,52 & 0,84 \\
\hline & Dyn-Gaussian & $-1,25$ & $-10,86$ & $-0,32$ & $-0,14$ & $-5,90$ & $-4,23$ & $-1,55$ & $-7,95$ & $-3,22$ \\
\hline & Dyn-Clayton & $-1,42$ & 0,17 & $-1,22$ & $-0,22$ & 0,15 & 0,14 & 0,14 & 0,14 & 0,15 \\
\hline & Dyn-Gumbel & 0,47 & $-3,64$ & 0,47 & 0,59 & 0,55 & 0,55 & 0,59 & 0,36 & 0,59 \\
\hline & Dyn-SJC & 0,70 & $-1,71$ & $-2,87$ & 0,62 & 1,95 & 1,47 & 1,34 & 1,07 & 1,72 \\
\hline
\end{tabular}




\begin{tabular}{|c|c|c|c|c|c|c|c|c|c|c|}
\hline \multirow[b]{2}{*}{ Province } & \multirow[b]{2}{*}{ Copula } & \multicolumn{9}{|c|}{ AIC Commodities } \\
\hline & & Paddy & Dryland paddy & Wet rice field & Maize & Mungbeans & Soybeans & Peanuts & $\begin{array}{c}\text { Sweet } \\
\text { potatoes }\end{array}$ & Cassava \\
\hline \multirow{8}{*}{ Sumatera Utara } & Stat-Gaussian & $-0,05$ & $-0,60$ & $-0,05$ & 0,02 & $-2,89$ & $-0,05$ & $-0,29$ & $-0,56$ & 0,03 \\
\hline & Stat-Clayton & 0,04 & $-0,76$ & 0,04 & 0,04 & 0,04 & $-0,43$ & 0,04 & $-0,21$ & $-0,23$ \\
\hline & Stat-Gumbel & 1,14 & 0,20 & 1,14 & 0,61 & 3,19 & 1,77 & 1,83 & $-0,20$ & 0,93 \\
\hline & Stat-SJC & 0,23 & $-0,44$ & 0,19 & 0,34 & 0,55 & $-0,17$ & 0,47 & $-0,40$ & 0,01 \\
\hline & Dyn-Gaussian & $-0,03$ & $-0,95$ & $-1,67$ & $-1,25$ & $-4,38$ & $-5,23$ & $-0,81$ & $-4,15$ & $-0,89$ \\
\hline & Dyn-Clayton & $-1,01$ & $-1,25$ & $-1,18$ & $-0,23$ & 0,14 & $-1,04$ & $-0,92$ & $-1,63$ & $-1,21$ \\
\hline & Dyn-Gumbel & $-0,02$ & $-0,40$ & $-0,03$ & 0,01 & 0,59 & 0,21 & 0,54 & $-0,76$ & $-0,07$ \\
\hline & Dyn-SJC & 0,55 & $-0,63$ & 0,53 & $-0,86$ & 1,57 & $-2,09$ & 0,85 & $-1,34$ & $-1,99$ \\
\hline \multirow{8}{*}{ Sumatera Barat } & Stat-Gaussian & $-0,10$ & $-1,42$ & $-0,08$ & 0,02 & 0,01 & $-0,04$ & $-0,83$ & $-0,04$ & 0,04 \\
\hline & Stat-Clayton & 0,04 & 0,04 & 0,04 & $-0,29$ & $-0,01$ & 0,04 & 0,04 & $-0,71$ & 0,03 \\
\hline & Stat-Gumbel & 1,42 & 2,85 & 1,37 & 1,03 & 0,92 & 1,61 & 2,63 & 0,77 & 1,44 \\
\hline & Stat-SJC & 0,30 & 0,87 & 0,30 & $-0,20$ & 0,09 & 0,27 & 0,81 & $-0,46$ & 0,36 \\
\hline & Dyn-Gaussian & $-0,67$ & $-3,49$ & $-0,62$ & $-1,11$ & $-3,05$ & $-5,19$ & $-1,14$ & $-2,38$ & $-0,61$ \\
\hline & Dyn-Clayton & $-1,45$ & 0,15 & $-1,45$ & $-1,76$ & $-0,18$ & $-0,04$ & $-0,25$ & $-1,04$ & $-0,28$ \\
\hline & Dyn-Gumbel & 0,59 & 0,21 & 0,59 & 0,47 & 0,04 & 0,49 & 0,59 & 0,34 & 0,34 \\
\hline & Dyn-SJC & $-2,84$ & 1,48 & $-2,76$ & $-2,01$ & 0,33 & 0,68 & 1,24 & $-0,17$ & 0,50 \\
\hline \multirow{8}{*}{ Riau } & Stat-Gaussian & $-0,31$ & 0,04 & $-0,30$ & 0,04 & $-0,36$ & $-2,21$ & $-1,50$ & 0,04 & 0,04 \\
\hline & Stat-Clayton & $-0,23$ & 0,04 & $-0,18$ & 0,04 & 0,04 & 0,04 & 0,04 & $-0,15$ & $-0,15$ \\
\hline & Stat-Gumbel & $-1,77$ & 1,10 & $-1,97$ & 0,13 & 2,14 & 3,03 & 2,69 & 1,36 & 1,48 \\
\hline & Stat-SJC & $-1,54$ & 0,21 & $-1,75$ & 0,14 & 0,32 & 0,44 & 0,87 & 0,04 & 0,24 \\
\hline & Dyn-Gaussian & $-2,74$ & $-2,10$ & $-3,57$ & $-1,88$ & $-1,13$ & $-2,90$ & $-3,47$ & $-0,42$ & $-3,98$ \\
\hline & Dyn-Clayton & $-0,81$ & 0,12 & $-1,43$ & $-0,04$ & $-0,49$ & 0,03 & $-0,01$ & $-0,12$ & $-0,66$ \\
\hline & Dyn-Gumbel & $-2,83$ & 0,05 & $-2,40$ & 0,00 & 0,55 & 0,55 & 0,59 & $-0,11$ & 0,08 \\
\hline & Dyn-SJC & $-5,89$ & 0,55 & $-4,03$ & $-1,34$ & 0,82 & 1,36 & 1,37 & $-0,39$ & $-2,50$ \\
\hline \multirow{8}{*}{ Jambi } & Stat-Gaussian & 0,02 & 0,03 & 0,04 & $-0,28$ & $-0,46$ & $-0,06$ & $-0,33$ & $-0,77$ & $-1,41$ \\
\hline & Stat-Clayton & $-0,09$ & 0,02 & $-0,16$ & 0,04 & $-0,01$ & 0,04 & 0,04 & 0,04 & 0,04 \\
\hline & Stat-Gumbel & 1,38 & 1,29 & 1,32 & 1,23 & 1,95 & 1,95 & 1,61 & 3,17 & 3,15 \\
\hline & Stat-SJC & $-0,01$ & 0,33 & 0,11 & 0,38 & 0,19 & 0,26 & 0,45 & 0,36 & 0,90 \\
\hline & Dyn-Gaussian & $-0,97$ & $-0,52$ & $-1,01$ & $-1,23$ & $-4,25$ & $-2,49$ & $-2,77$ & $-3,22$ & $-3,87$ \\
\hline & Dyn-Clayton & $-1,38$ & $-1,32$ & $-1,31$ & 0,14 & $-0,45$ & $-2,00$ & 0,14 & $-1,06$ & 0,14 \\
\hline & Dyn-Gumbel & 0,51 & 0,47 & 0,51 & 0,45 & 0,43 & 0,43 & 0,42 & 0,44 & 0,24 \\
\hline & Dyn-SJC & $-2,11$ & $-1,78$ & $-2,10$ & 0,79 & $-1,71$ & $-3,02$ & 0,85 & 1,17 & 1,54 \\
\hline \multirow{8}{*}{$\begin{array}{l}\text { Sumatera } \\
\text { Selatan }\end{array}$} & Stat-Gaussian & 0,04 & $-5,66$ & 0,03 & $-0,20$ & 0,01 & $-0,41$ & 0,00 & 0,04 & $-1,45$ \\
\hline & Stat-Clayton & $-0,19$ & $-3,29$ & $-0,19$ & $-0,63$ & $-0,18$ & 0,04 & 0,02 & 0,04 & 0,04 \\
\hline & Stat-Gumbel & 0,98 & $-4,93$ & 1,05 & 0,08 & 0,35 & 2,01 & $-0,16$ & 0,43 & 2,65 \\
\hline & Stat-SJC & $-0,16$ & $-5,18$ & 0,07 & $-0,71$ & $-0,22$ & 0,46 & $-0,17$ & 0,26 & 0,82 \\
\hline & Dyn-Gaussian & $-0,88$ & $-12,28$ & $-1,40$ & $-5,89$ & $-0,16$ & $-1,10$ & $-2,00$ & $-1,77$ & $-4,00$ \\
\hline & Dyn-Clayton & $-1,46$ & $-3,25$ & $-1,49$ & $-2,42$ & $-0,95$ & $-0,48$ & $-0,82$ & 0,02 & 0,17 \\
\hline & Dyn-Gumbel & 0,45 & $-5,99$ & 0,47 & $-0,82$ & 0,10 & 0,59 & $-2,00$ & 0,06 & 0,52 \\
\hline & Dyn-SJC & $-1,73$ & $-11,26$ & $-2,07$ & $-3,18$ & $-1,00$ & 0,86 & $-2,86$ & 0,30 & 1,30 \\
\hline \multirow{8}{*}{ Bengkulu } & Stat-Gaussian & 0,00 & $-1,89$ & $-0,02$ & 0,01 & $-0,71$ & $-3,82$ & $-0,73$ & $-3,91$ & $-1,64$ \\
\hline & Stat-Clayton & 0,04 & 0,05 & 0,04 & 0,04 & 0,04 & 0,04 & 0,04 & 0,04 & 0,04 \\
\hline & Stat-Gumbel & 1,10 & 2,59 & 1,25 & 0,65 & 2,58 & 4,05 & 1,77 & 3,45 & 3,03 \\
\hline & Stat-SJC & 0,38 & 0,51 & 0,39 & 0,07 & 0,45 & 0,57 & 0,30 & 0,58 & 0,87 \\
\hline & Dyn-Gaussian & $-2,47$ & $-3,86$ & $-0,73$ & $-0,76$ & $-2,41$ & $-9,72$ & $-3,29$ & $-9,96$ & $-5,76$ \\
\hline & Dyn-Clayton & $-0,84$ & 0,17 & $-1,70$ & $-0,25$ & $-1,51$ & $-0,32$ & $-1,13$ & 0,14 & $-0,63$ \\
\hline & Dyn-Gumbel & 0,43 & $-0,13$ & 0,51 & 0,20 & 0,59 & 0,52 & 0,52 & 0,52 & 0,47 \\
\hline & Dyn-SJC & 0,53 & 1,73 & $-3,28$ & $-1,23$ & $-2,17$ & 1,70 & $-1,64$ & 1,75 & 1,43 \\
\hline
\end{tabular}




\begin{tabular}{|c|c|c|c|c|c|c|c|c|c|c|}
\hline \multirow[b]{2}{*}{ Province } & \multirow[b]{2}{*}{ Copula } & \multicolumn{9}{|c|}{ AIC Commodities } \\
\hline & & Paddy & Dryland paddy & Wet rice field & Maize & Mungbeans & Soybeans & Peanuts & $\begin{array}{c}\text { Sweet } \\
\text { potatoes }\end{array}$ & Cassava \\
\hline \multirow{8}{*}{ Lampung } & Stat-Gaussian & $-0,01$ & $-0,03$ & $-0,01$ & $-0,43$ & $-0,63$ & $-0,36$ & $-0,29$ & $-0,49$ & 0,01 \\
\hline & Stat-Clayton & 0,04 & 0,04 & 0,03 & $-0,12$ & 0,04 & 0,04 & $-0,08$ & $-0,69$ & 0,04 \\
\hline & Stat-Gumbel & 1,22 & 1,29 & 1,26 & $-1,31$ & 2,43 & 2,39 & $-1,19$ & 0,16 & $-1,08$ \\
\hline & Stat-SJC & 0,46 & 0,24 & 0,36 & $-1,24$ & 0,46 & 0,45 & $-0,95$ & $-0,60$ & $-0,98$ \\
\hline & Dyn-Gaussian & $-0,18$ & $-0,73$ & $-0,45$ & $-0,54$ & $-0,62$ & $-5,15$ & $-7,29$ & $-1,52$ & $-0,21$ \\
\hline & Dyn-Clayton & $-0,82$ & $-0,08$ & $-1,40$ & $-0,49$ & 0,13 & 0,14 & $-1,02$ & $-1,10$ & $-0,85$ \\
\hline & Dyn-Gumbel & 0,54 & 0,07 & 0,58 & $-1,47$ & 0,55 & 0,40 & $-4,72$ & $-0,28$ & $-1,60$ \\
\hline & Dyn-SJC & $-1,23$ & $-1,77$ & $-2,90$ & $-2,56$ & 1,07 & 1,11 & $-6,63$ & $-0,72$ & $-2,66$ \\
\hline \multirow{8}{*}{$\begin{array}{l}\text { Kepulauan } \\
\text { Bangka } \\
\text { Belitung }\end{array}$} & Stat-Gaussian & $-0,09$ & $-0,36$ & $-0,03$ & $-0,03$ & $-0,07$ & 0,00 & 0,03 & $-0,06$ & $-0,09$ \\
\hline & Stat-Clayton & 0,04 & 0,04 & 0,04 & 0,04 & 0,04 & 0,04 & 0,04 & 0,04 & 0,04 \\
\hline & Stat-Gumbel & 1,63 & 2,00 & 1,36 & 1,57 & 1,54 & $-1,48$ & 0,86 & 1,50 & 1,50 \\
\hline & Stat-SJC & 0,51 & 0,32 & 0,46 & 0,24 & 0,19 & $-1,32$ & 0,21 & 0,25 & 0,30 \\
\hline & Dyn-Gaussian & $-0,29$ & $-0,80$ & $-0,17$ & $-0,14$ & $-0,23$ & $-3,00$ & $-0,06$ & $-0,23$ & $-0,31$ \\
\hline & Dyn-Clayton & $-0,81$ & $-0,89$ & $-0,77$ & $-0,82$ & $-0,80$ & $-0,76$ & $-0,82$ & $-0,79$ & $-0,86$ \\
\hline & Dyn-Gumbel & 0,59 & 0,59 & 0,56 & 0,59 & 0,59 & $-1,72$ & 0,49 & 0,59 & 0,59 \\
\hline & Dyn-SJC & $-1,14$ & 0,76 & $-1,23$ & $-1,26$ & 0,49 & $-1,55$ & 0,32 & $-1,25$ & $-1,23$ \\
\hline \multirow{8}{*}{$\begin{array}{l}\text { Kepulauan } \\
\text { Riau }\end{array}$} & Stat-Gaussian & $-0,06$ & 0,01 & $-0,06$ & 0,01 & $-0,08$ & $-0,12$ & 0,00 & 0,00 & $-0,03$ \\
\hline & Stat-Clayton & 0,04 & 0,04 & 0,04 & 0,04 & 0,04 & 0,04 & 0,04 & 0,04 & 0,04 \\
\hline & Stat-Gumbel & 1,26 & 1,24 & 1,26 & 1,21 & 1,38 & 1,33 & 1,22 & 1,22 & 1,30 \\
\hline & Stat-SJC & 0,33 & 0,41 & 0,33 & 0,20 & 0,34 & 0,19 & 0,42 & 0,44 & 0,46 \\
\hline & Dyn-Gaussian & $-0,23$ & $-0,10$ & $-0,23$ & $-0,11$ & $-0,28$ & $-0,34$ & $-0,13$ & $-0,10$ & $-0,18$ \\
\hline & Dyn-Clayton & $-0,69$ & $-0,80$ & $-0,69$ & $-0,73$ & $-0,81$ & $-0,72$ & $-0,69$ & $-0,78$ & $-0,82$ \\
\hline & Dyn-Gumbel & 0,59 & 0,59 & 0,59 & 0,59 & 0,58 & 0,59 & 0,59 & 0,58 & 0,59 \\
\hline & Dyn-SJC & $-1,25$ & $-1,29$ & $-1,25$ & 0,36 & $-1,23$ & 0,48 & $-1,28$ & $-1,26$ & $-1,23$ \\
\hline \multirow{8}{*}{$\begin{array}{l}\text { Daerah Khusus } \\
\text { Ibukota } \\
\text { Jakarta }\end{array}$} & Stat-Gaussian & $-0,36$ & $-0,43$ & $-0,43$ & $-0,62$ & $-0,08$ & $-0,08$ & $-0,46$ & 0,02 & $-0,20$ \\
\hline & Stat-Clayton & 0,04 & $-0,24$ & 0,04 & $-0,44$ & 0,04 & 0,04 & $-0,47$ & 0,04 & 0,00 \\
\hline & Stat-Gumbel & 2,55 & $-0,29$ & 2,66 & $-0,21$ & 1,38 & 1,38 & $-0,14$ & 0,76 & $-0,68$ \\
\hline & Stat-SJC & 0,72 & $-0,33$ & 0,74 & $-0,50$ & 0,34 & 0,34 & $-0,55$ & 0,06 & $-0,75$ \\
\hline & Dyn-Gaussian & $-4,26$ & $-1,19$ & $-3,91$ & $-2,19$ & $-0,28$ & $-0,28$ & $-2,11$ & $-0,23$ & $-0,52$ \\
\hline & Dyn-Clayton & 0,14 & $-1,98$ & 0,14 & $-1,01$ & $-0,81$ & $-0,81$ & $-1,36$ & $-0,80$ & $-0,30$ \\
\hline & Dyn-Gumbel & 0,21 & $-2,15$ & 0,25 & $-0,65$ & 0,58 & 0,58 & $-0,74$ & $-0,26$ & $-1,44$ \\
\hline & Dyn-SJC & 1,13 & $-0,24$ & 1,17 & $-0,66$ & $-1,23$ & $-1,23$ & $-1,02$ & 0,42 & $-6,23$ \\
\hline \multirow{8}{*}{ Jawa Barat } & Stat-Gaussian & $-0,14$ & 0,03 & $-0,11$ & $-0,17$ & 0,02 & $-1,47$ & $-0,35$ & $-0,96$ & 0,04 \\
\hline & Stat-Clayton & 0,04 & 0,04 & 0,04 & 0,04 & 0,04 & 0,04 & 0,04 & $-0,43$ & 0,04 \\
\hline & Stat-Gumbel & 1,43 & 1,05 & 1,38 & 0,56 & 1,02 & 3,32 & 1,90 & $-0,43$ & 0,95 \\
\hline & Stat-SJC & 0,30 & 0,33 & 0,29 & 0,06 & 0,26 & 0,46 & 0,49 & $-0,61$ & 0,22 \\
\hline & Dyn-Gaussian & $-2,51$ & $-0,70$ & $-2,36$ & $-4,12$ & $-0,85$ & $-12,10$ & $-0,95$ & $-3,08$ & $-0,55$ \\
\hline & Dyn-Clayton & 0,14 & 0,15 & 0,14 & $-0,67$ & 0,13 & 0,15 & 0,16 & $-4,96$ & 0,13 \\
\hline & Dyn-Gumbel & 0,41 & 0,25 & 0,41 & 0,24 & 0,38 & 0,42 & 0,38 & $-0,39$ & 0,01 \\
\hline & Dyn-SJC & 0,80 & 0,65 & 0,78 & 0,24 & 0,64 & 1,51 & 1,06 & $-7,06$ & 0,55 \\
\hline \multirow{8}{*}{ Jawa Tengah } & Stat-Gaussian & 0,04 & 0,04 & $-0,03$ & $-0,58$ & 0,04 & 0,04 & 0,04 & $-0,20$ & $-0,13$ \\
\hline & Stat-Clayton & 0,04 & 0,04 & 0,04 & $-0,29$ & 0,04 & 0,04 & 0,04 & 0,04 & 0,04 \\
\hline & Stat-Gumbel & 0,92 & 0,81 & 1,17 & $-0,50$ & 1,23 & 1,29 & $-0,12$ & $-1,59$ & 1,14 \\
\hline & Stat-SJC & 0,28 & 0,22 & 0,32 & $-0,49$ & 0,29 & 0,18 & $-0,29$ & $-2,00$ & 0,25 \\
\hline & Dyn-Gaussian & $-0,88$ & $-2,32$ & $-1,94$ & $-4,71$ & $-1,11$ & $-5,85$ & $-1,37$ & $-1,63$ & $-1,12$ \\
\hline & Dyn-Clayton & $-1,07$ & $-0,91$ & $-0,42$ & $-3,95$ & $-2,01$ & 0,13 & 0,15 & 0,14 & 0,16 \\
\hline & Dyn-Gumbel & 0,40 & 0,35 & 0,40 & $-0,55$ & 0,33 & 0,38 & $-1,21$ & $-1,98$ & $-0,06$ \\
\hline & Dyn-SJC & 0,54 & 0,42 & 0,70 & $-10,11$ & 0,58 & 0,48 & 0,01 & $-2,90$ & 0,77 \\
\hline
\end{tabular}




\begin{tabular}{|c|c|c|c|c|c|c|c|c|c|c|}
\hline \multirow[b]{2}{*}{ Province } & \multirow[b]{2}{*}{ Copula } & \multicolumn{9}{|c|}{ AIC Commodities } \\
\hline & & Paddy & Dryland paddy & Wet rice field & Maize & Mungbeans & Soybeans & Peanuts & $\begin{array}{l}\text { Sweet } \\
\text { potatoes }\end{array}$ & Cassava \\
\hline \multirow{8}{*}{$\begin{array}{l}\text { Daerah } \\
\text { Istimewa } \\
\text { Yogyakarta }\end{array}$} & Stat-Gaussian & 0,00 & 0,04 & $-0,13$ & $-1,33$ & $-0,09$ & $-0,48$ & $-0,44$ & 0,03 & $-0,17$ \\
\hline & Stat-Clayton & 0,00 & $-0,01$ & 0,04 & $-1,77$ & $-0,25$ & 0,04 & 0,04 & 0,04 & $-0,58$ \\
\hline & Stat-Gumbel & 1,43 & 1,13 & 1,49 & $-2,05$ & $-0,29$ & 1,92 & 2,01 & 0,20 & $-0,18$ \\
\hline & Stat-SJC & 0,33 & 0,28 & 0,29 & $-2,33$ & $-0,35$ & 0,46 & 0,32 & 0,03 & $-0,67$ \\
\hline & Dyn-Gaussian & $-0,51$ & $-0,35$ & $-0,78$ & $-2,53$ & $-4,33$ & $-0,63$ & $-1,59$ & $-6,72$ & $-1,29$ \\
\hline & Dyn-Clayton & $-1,42$ & $-0,86$ & $-1,58$ & $-4,03$ & $-4,10$ & 0,13 & $-0,99$ & 0,14 & $-1,81$ \\
\hline & Dyn-Gumbel & 0,59 & 0,54 & 0,59 & $-2,02$ & $-2,65$ & 0,52 & 0,55 & $-1,26$ & $-0,24$ \\
\hline & Dyn-SJC & $-2,98$ & $-1,10$ & $-3,10$ & $-4,22$ & $-2,44$ & 0,96 & 0,81 & $-2,88$ & $-3,44$ \\
\hline \multirow{8}{*}{ Jawa Timur } & Stat-Gaussian & $-0,04$ & 0,02 & $-0,04$ & $-0,18$ & 0,02 & $-2,54$ & 0,04 & 0,01 & $-0,71$ \\
\hline & Stat-Clayton & 0,04 & 0,04 & 0,04 & $-0,84$ & 0,04 & 0,05 & $-0,35$ & 0,04 & 0,04 \\
\hline & Stat-Gumbel & 1,05 & 1,05 & 1,03 & 0,43 & 1,42 & 3,41 & 1,11 & $-0,49$ & 3,07 \\
\hline & Stat-SJC & 0,31 & 0,11 & 0,44 & $-0,91$ & 0,42 & 0,87 & $-0,30$ & $-0,58$ & 0,52 \\
\hline & Dyn-Gaussian & $-0,20$ & $-0,18$ & $-0,19$ & $-0,92$ & $-0,06$ & $-5,34$ & $-1,57$ & $-3,35$ & $-1,24$ \\
\hline & Dyn-Clayton & $-0,81$ & $-0,29$ & $-0,81$ & $-1,29$ & $-0,68$ & 0,15 & $-1,45$ & 0,15 & 0,15 \\
\hline & Dyn-Gumbel & 0,30 & 0,47 & 0,21 & 0,11 & 0,59 & 0,33 & 0,35 & $-4,32$ & 0,47 \\
\hline & Dyn-SJC & $-1,37$ & 0,33 & $-1,54$ & $-2,06$ & $-1,24$ & 1,84 & $-1,85$ & $-0,63$ & 1,27 \\
\hline \multirow{8}{*}{ Banten } & Stat-Gaussian & $-0,01$ & $-0,04$ & $-0,06$ & 0,04 & $-0,12$ & 0,04 & 0,04 & 0,01 & 0,01 \\
\hline & Stat-Clayton & 0,04 & 0,04 & 0,04 & 0,04 & 0,04 & 0,04 & 0,04 & 0,04 & 0,04 \\
\hline & Stat-Gumbel & 0,90 & $-1,34$ & 1,20 & 0,67 & 1,84 & $-0,47$ & $-0,87$ & 0,83 & 1,42 \\
\hline & Stat-SJC & 0,28 & $-1,18$ & 0,46 & 0,14 & 0,30 & $-0,33$ & $-0,58$ & 0,38 & 0,30 \\
\hline & Dyn-Gaussian & $-0,16$ & $-1,35$ & $-0,26$ & $-0,66$ & $-0,35$ & $-0,09$ & $-0,95$ & $-0,11$ & $-0,08$ \\
\hline & Dyn-Clayton & $-0,80$ & $-0,67$ & $-0,81$ & $-0,80$ & $-0,77$ & $-0,65$ & $-0,82$ & $-0,75$ & $-0,76$ \\
\hline & Dyn-Gumbel & 0,24 & $-1,40$ & 0,51 & 0,39 & 0,59 & $-0,45$ & $-0,83$ & 0,45 & 0,59 \\
\hline & Dyn-SJC & 0,42 & $-4,95$ & $-1,22$ & $-1,58$ & 0,64 & $-0,41$ & $-2,88$ & $-1,32$ & $-1,26$ \\
\hline \multirow{8}{*}{ Bali } & Stat-Gaussian & 0,00 & $-0,25$ & $-0,01$ & $-0,23$ & $-0,13$ & $-1,69$ & $-0,09$ & 0,01 & $-0,31$ \\
\hline & Stat-Clayton & 0,04 & 0,04 & 0,04 & $-0,15$ & 0,04 & 0,04 & 0,04 & 0,04 & 0,04 \\
\hline & Stat-Gumbel & 0,77 & $-1,61$ & 0,73 & 1,91 & 1,26 & 2,86 & 1,90 & 0,10 & 2,53 \\
\hline & Stat-SJC & 0,33 & $-1,73$ & 0,32 & 0,05 & 0,28 & 0,41 & 0,26 & $-0,24$ & 0,35 \\
\hline & Dyn-Gaussian & $-0,77$ & $-3,55$ & $-0,80$ & $-3,61$ & $-1,10$ & $-2,41$ & $-0,86$ & $-0,10$ & $-1,66$ \\
\hline & Dyn-Clayton & $-1,04$ & $-0,88$ & $-1,13$ & $-0,29$ & $-1,21$ & 0,12 & $-0,66$ & $-1,96$ & $-1,58$ \\
\hline & Dyn-Gumbel & 0,40 & $-4,72$ & 0,40 & 0,39 & 0,38 & 0,36 & 0,39 & $-1,74$ & 0,28 \\
\hline & Dyn-SJC & 0,23 & $-4,74$ & $-1,35$ & 0,02 & 0,55 & 1,36 & 0,72 & $-5,69$ & 1,01 \\
\hline \multirow{8}{*}{$\begin{array}{l}\text { Nusa Tenggara } \\
\text { Barat }\end{array}$} & Stat-Gaussian & 0,00 & $-0,92$ & $-0,08$ & 0,04 & $-0,07$ & $-1,05$ & $-0,25$ & 0,01 & $-0,08$ \\
\hline & Stat-Clayton & 0,03 & $-2,14$ & 0,04 & $-0,19$ & 0,02 & 0,04 & 0,04 & 0,04 & 0,04 \\
\hline & Stat-Gumbel & 1,12 & $-0,16$ & 1,58 & 1,16 & $-0,44$ & 3,09 & 2,14 & $-0,41$ & 1,32 \\
\hline & Stat-SJC & 0,36 & $-2,12$ & 0,20 & $-0,03$ & $-0,35$ & 0,78 & 0,47 & $-0,63$ & 0,32 \\
\hline & Dyn-Gaussian & $-0,46$ & $-4,00$ & $-0,64$ & $-1,02$ & $-0,18$ & $-4,23$ & $-0,26$ & $-5,29$ & $-4,45$ \\
\hline & Dyn-Clayton & $-0,83$ & $-2,92$ & $-0,93$ & $-0,84$ & $-0,53$ & $-0,93$ & $-0,14$ & 0,14 & 0,13 \\
\hline & Dyn-Gumbel & 0,48 & $-0,44$ & 0,52 & 0,32 & $-0,57$ & 0,47 & 0,55 & $-1,03$ & $-0,31$ \\
\hline & Dyn-SJC & $-2,14$ & $-3,41$ & $-2,06$ & $-0,71$ & $-0,27$ & 1,25 & 0,93 & $-1,80$ & 0,98 \\
\hline \multirow{8}{*}{$\begin{array}{l}\text { Nusa Tenggara } \\
\text { Timur }\end{array}$} & Stat-Gaussian & $-0,06$ & $-0,43$ & 0,01 & 0,02 & $-0,45$ & $-2,24$ & $-0,47$ & $-1,39$ & $-0,13$ \\
\hline & Stat-Clayton & $-0,02$ & 0,02 & $-0,15$ & $-0,30$ & 0,05 & 0,04 & $-0,44$ & $-2,43$ & $-0,49$ \\
\hline & Stat-Gumbel & 1,52 & 2,31 & 1,38 & 0,53 & 1,89 & 3,45 & $-0,92$ & $-0,34$ & $-1,00$ \\
\hline & Stat-SJC & 0,12 & 0,30 & $-0,09$ & $-0,35$ & 0,47 & 0,44 & $-0,91$ & $-2,11$ & $-0,84$ \\
\hline & Dyn-Gaussian & $-1,25$ & $-5,97$ & $-1,14$ & $-2,53$ & $-2,16$ & $-8,16$ & $-1,31$ & $-6,52$ & $-0,36$ \\
\hline & Dyn-Clayton & $-1,74$ & $-1,56$ & $-1,66$ & $-1,82$ & 0,14 & $-1,01$ & $-1,60$ & $-5,11$ & $-1,35$ \\
\hline & Dyn-Gumbel & 0,54 & 0,33 & 0,54 & $-0,03$ & 0,59 & 0,52 & $-0,99$ & $-1,91$ & $-2,60$ \\
\hline & Dyn-SJC & $-1,87$ & $-2,40$ & $-1,89$ & $-2,60$ & 0,91 & 1,40 & $-7,43$ & $-2,22$ & $-5,35$ \\
\hline
\end{tabular}




\begin{tabular}{|c|c|c|c|c|c|c|c|c|c|c|}
\hline \multirow[b]{2}{*}{ Province } & \multirow[b]{2}{*}{ Copula } & \multicolumn{9}{|c|}{ AIC Commodities } \\
\hline & & Paddy & Dryland paddy & Wet rice field & Maize & Mungbeans & Soybeans & Peanuts & $\begin{array}{c}\text { Sweet } \\
\text { potatoes }\end{array}$ & Cassava \\
\hline \multirow{8}{*}{$\begin{array}{l}\text { Kalimantan } \\
\text { Barat }\end{array}$} & Stat-Gaussian & 0,04 & $-0,93$ & 0,03 & $-0,24$ & $-1,90$ & $-1,11$ & $-0,91$ & $-2,00$ & $-2,42$ \\
\hline & Stat-Clayton & 0,04 & 0,04 & 0,04 & $-0,33$ & $-2,96$ & 0,04 & 0,04 & 0,04 & 0,04 \\
\hline & Stat-Gumbel & 0,66 & 3,02 & 0,75 & $-0,97$ & $-0,55$ & 2,83 & 2,82 & 2,99 & 3,68 \\
\hline & Stat-SJC & 0,26 & 0,47 & 0,31 & $-0,97$ & $-2,47$ & 0,77 & 0,79 & 0,90 & 0,49 \\
\hline & Dyn-Gaussian & $-1,09$ & $-3,01$ & $-0,06$ & $-0,88$ & $-6,02$ & $-3,77$ & $-1,67$ & $-3,46$ & $-5,35$ \\
\hline & Dyn-Clayton & $-0,66$ & $-1,67$ & $-0,65$ & $-1,37$ & $-5,33$ & 0,14 & $-0,75$ & 0,15 & 0,14 \\
\hline & Dyn-Gumbel & 0,43 & 0,55 & 0,47 & $-1,10$ & $-0,48$ & 0,55 & 0,52 & 0,59 & 0,06 \\
\hline & Dyn-SJC & $-2,21$ & $-1,31$ & $-1,82$ & $-2,02$ & $-5,24$ & 1,19 & 1,24 & 1,46 & 1,78 \\
\hline \multirow{8}{*}{$\begin{array}{l}\text { Kalimantan } \\
\text { Tengah }\end{array}$} & Stat-Gaussian & $-0,42$ & 0,03 & $-0,72$ & $-0,66$ & $-0,45$ & 0,04 & 0,04 & $-0,25$ & $-0,04$ \\
\hline & Stat-Clayton & 0,04 & $-0,06$ & 0,04 & $-0,91$ & 0,04 & 0,04 & $-0,25$ & 0,04 & $-0,07$ \\
\hline & Stat-Gumbel & 1,74 & 0,66 & 1,95 & $-0,01$ & 2,03 & 0,63 & 1,12 & 1,76 & 1,22 \\
\hline & Stat-SJC & 0,27 & 0,04 & 0,45 & $-0,83$ & 0,33 & 0,12 & $-0,19$ & 0,31 & $-0,01$ \\
\hline & Dyn-Gaussian & $-1,98$ & $-2,27$ & $-1,62$ & $-1,18$ & $-1,18$ & $-5,26$ & $-2,56$ & $-1,01$ & $-1,13$ \\
\hline & Dyn-Clayton & $-1,72$ & $-1,78$ & $-1,40$ & $-3,43$ & $-0,68$ & $-1,20$ & $-2,49$ & $-1,51$ & $-1,17$ \\
\hline & Dyn-Gumbel & 0,54 & 0,19 & 0,59 & $-0,04$ & 0,59 & $-0,43$ & 0,16 & 0,35 & 0,49 \\
\hline & Dyn-SJC & $-1,73$ & $-2,28$ & 0,92 & $-5,51$ & 0,83 & $-1,37$ & $-2,49$ & 0,73 & $-3,30$ \\
\hline \multirow{8}{*}{$\begin{array}{l}\text { Kalimantan } \\
\text { Selatan }\end{array}$} & Stat-Gaussian & $-0,15$ & 0,02 & $-0,13$ & $-0,02$ & 0,04 & $-2,42$ & 0,04 & 0,04 & 0,04 \\
\hline & Stat-Clayton & 0,04 & 0,02 & 0,04 & 0,04 & $-0,23$ & 0,05 & 0,04 & 0,04 & 0,01 \\
\hline & Stat-Gumbel & 1,68 & 0,59 & 1,69 & 0,87 & 1,17 & 3,34 & 1,05 & 0,69 & 0,84 \\
\hline & Stat-SJC & 0,29 & 0,10 & 0,24 & 0,22 & $-0,09$ & 0,71 & 0,22 & 0,34 & 0,27 \\
\hline & Dyn-Gaussian & $-0,37$ & $-2,61$ & $-0,33$ & $-0,91$ & $-0,24$ & $-4,39$ & $-0,18$ & $-3,36$ & $-2,74$ \\
\hline & Dyn-Clayton & $-0,59$ & $-1,52$ & $-0,55$ & $-0,13$ & $-0,34$ & 0,14 & $-0,77$ & 0,13 & $-0,73$ \\
\hline & Dyn-Gumbel & 0,54 & $-0,21$ & 0,54 & 0,16 & 0,31 & 0,47 & 0,39 & 0,34 & $-0,01$ \\
\hline & Dyn-SJC & 0,64 & $-4,18$ & 0,58 & 0,49 & $-0,76$ & 1,70 & $-0,91$ & 0,51 & $-1,69$ \\
\hline \multirow{8}{*}{$\begin{array}{l}\text { Kalimantan } \\
\text { Timur }\end{array}$} & Stat-Gaussian & 0,04 & $-2,13$ & $-0,01$ & 0,03 & $-1,08$ & $-0,41$ & $-0,24$ & 0,04 & $-0,30$ \\
\hline & Stat-Clayton & 0,04 & 0,05 & 0,04 & 0,04 & 0,04 & 0,03 & 0,04 & 0,04 & 0,04 \\
\hline & Stat-Gumbel & $-1,17$ & 2,88 & $-1,59$ & 1,05 & 2,65 & 2,21 & 2,10 & $-0,80$ & 1,29 \\
\hline & Stat-SJC & $-1,16$ & 0,94 & $-1,66$ & 0,35 & 0,78 & 0,27 & 0,30 & $-0,70$ & 0,28 \\
\hline & Dyn-Gaussian & $-2,29$ & $-3,12$ & $-1,88$ & $-1,64$ & $-1,61$ & $-2,73$ & $-0,75$ & $-4,61$ & $-0,59$ \\
\hline & Dyn-Clayton & 0,14 & 0,15 & $-0,27$ & $-0,44$ & $-0,17$ & $-1,66$ & $-0,43$ & $-1,14$ & 0,14 \\
\hline & Dyn-Gumbel & $-1,14$ & 0,33 & $-1,58$ & 0,30 & 0,55 & 0,52 & 0,55 & $-0,91$ & 0,37 \\
\hline & Dyn-SJC & $-1,31$ & 1,64 & $-2,55$ & 0,50 & 1,21 & $-1,66$ & 0,73 & $-1,25$ & 0,75 \\
\hline \multirow{8}{*}{$\begin{array}{l}\text { Kalimantan } \\
\text { Utara }\end{array}$} & Stat-Gaussian & $-0,09$ & $-0,19$ & $-0,08$ & $-0,07$ & $-0,20$ & $-0,19$ & $-0,24$ & $-0,08$ & $-0,11$ \\
\hline & Stat-Clayton & 0,04 & 0,04 & 0,04 & 0,04 & 0,04 & 0,04 & 0,04 & 0,04 & 0,04 \\
\hline & Stat-Gumbel & 1,34 & 1,39 & 1,32 & 1,38 & 1,42 & 1,42 & 1,44 & 1,32 & 1,39 \\
\hline & Stat-SJC & 0,33 & 0,20 & 0,32 & 0,34 & 0,31 & 0,28 & 0,37 & 0,32 & 0,24 \\
\hline & Dyn-Gaussian & $-0,29$ & $-0,49$ & $-0,27$ & $-0,25$ & $-0,50$ & $-0,50$ & $-0,57$ & $-0,27$ & $-0,32$ \\
\hline & Dyn-Clayton & $-0,72$ & $-0,77$ & $-0,73$ & $-0,80$ & $-0,78$ & $-0,83$ & $-0,77$ & $-0,73$ & $-0,79$ \\
\hline & Dyn-Gumbel & 0,59 & 0,59 & 0,59 & 0,59 & 0,59 & 0,59 & 0,59 & 0,59 & 0,59 \\
\hline & Dyn-SJC & $-1,25$ & 0,52 & $-1,26$ & $-1,23$ & 0,66 & 0,60 & 0,72 & $-1,26$ & 0,56 \\
\hline \multirow{8}{*}{ Sulawesi Utara } & Stat-Gaussian & $-0,03$ & $-0,48$ & $-0,03$ & $-1,02$ & $-0,60$ & $-1,73$ & 0,04 & 0,04 & $-0,31$ \\
\hline & Stat-Clayton & 0,00 & $-0,13$ & $-0,01$ & $-1,86$ & 0,03 & 0,04 & $-0,11$ & 0,04 & 0,04 \\
\hline & Stat-Gumbel & 1,34 & 0,16 & 1,33 & $-0,69$ & 1,90 & 3,03 & 1,03 & 0,52 & $-0,31$ \\
\hline & Stat-SJC & 0,31 & $-0,15$ & 0,30 & $-2,00$ & 0,27 & 0,58 & $-0,04$ & 0,26 & $-0,58$ \\
\hline & Dyn-Gaussian & $-1,01$ & $-0,45$ & $-1,01$ & $-1,56$ & $-2,83$ & $-5,23$ & $-0,47$ & $-0,28$ & $-1,88$ \\
\hline & Dyn-Clayton & $-1,78$ & $-0,66$ & $-1,76$ & $-2,57$ & $-1,47$ & $-0,56$ & $-1,72$ & 0,15 & 0,12 \\
\hline & Dyn-Gumbel & 0,54 & $-1,38$ & 0,54 & $-1,55$ & 0,52 & 0,55 & $-2,84$ & $-0,04$ & $-0,70$ \\
\hline & Dyn-SJC & $-1,93$ & 0,00 & $-1,93$ & $-2,05$ & $-1,57$ & 1,29 & $-2,01$ & 0,44 & $-2,94$ \\
\hline
\end{tabular}




\begin{tabular}{|c|c|c|c|c|c|c|c|c|c|c|}
\hline \multirow[b]{2}{*}{ Province } & \multirow[b]{2}{*}{ Copula } & \multicolumn{9}{|c|}{ AIC Commodities } \\
\hline & & Paddy & Dryland paddy & Wet rice field & Maize & Mungbeans & Soybeans & Peanuts & $\begin{array}{l}\text { Sweet } \\
\text { potatoes }\end{array}$ & Cassava \\
\hline \multirow{8}{*}{$\begin{array}{l}\text { Sulawesi } \\
\text { Tengah }\end{array}$} & Stat-Gaussian & $-0,02$ & $-0,79$ & $-0,03$ & $-1,73$ & $-1,65$ & $-2,72$ & 0,02 & $-0,67$ & 0,03 \\
\hline & Stat-Clayton & 0,04 & $-0,32$ & 0,04 & $-2,10$ & 0,04 & 0,04 & 0,04 & 0,04 & 0,04 \\
\hline & Stat-Gumbel & 1,28 & $-0,55$ & 1,26 & $-0,77$ & 3,20 & 3,41 & 0,19 & 1,96 & 1,07 \\
\hline & Stat-SJC & 0,30 & $-0,58$ & 0,25 & $-1,73$ & 0,44 & 0,50 & $-0,10$ & 0,45 & 0,30 \\
\hline & Dyn-Gaussian & $-0,11$ & $-5,58$ & $-0,10$ & $-1,78$ & $-2,18$ & $-6,30$ & $-0,94$ & $-1,61$ & $-4,10$ \\
\hline & Dyn-Clayton & $-0,85$ & $-1,01$ & $-0,71$ & $-2,98$ & 0,13 & 0,14 & 0,13 & 0,14 & 0,13 \\
\hline & Dyn-Gumbel & 0,59 & $-0,72$ & 0,59 & $-1,10$ & 0,59 & 0,44 & 0,01 & 0,52 & 0,43 \\
\hline & Dyn-SJC & 0,49 & $-4,27$ & 0,48 & $-3,15$ & 1,29 & 1,63 & $-0,43$ & 0,91 & 0,57 \\
\hline \multirow{8}{*}{$\begin{array}{l}\text { Sulawesi } \\
\text { Selatan }\end{array}$} & Stat-Gaussian & 0,04 & $-0,13$ & 0,04 & 0,03 & $-1,23$ & $-2,90$ & 0,04 & $-0,51$ & $-0,83$ \\
\hline & Stat-Clayton & $-0,28$ & $-0,09$ & $-0,28$ & $-0,40$ & 0,04 & 0,04 & $-0,26$ & 0,04 & 0,04 \\
\hline & Stat-Gumbel & 0,81 & 0,33 & 0,85 & 0,84 & 2,52 & 3,57 & 1,67 & 2,38 & 2,27 \\
\hline & Stat-SJC & $-0,27$ & 0,02 & $-0,30$ & $-0,49$ & 0,80 & 0,45 & $-0,18$ & 0,49 & 0,54 \\
\hline & Dyn-Gaussian & $-2,24$ & $-0,41$ & $-2,27$ & $-1,62$ & $-5,53$ & $-8,06$ & $-2,23$ & $-0,49$ & $-1,09$ \\
\hline & Dyn-Clayton & $-1,59$ & $-0,96$ & $-1,60$ & $-1,82$ & 0,13 & $-0,33$ & $-1,59$ & 0,13 & 0,16 \\
\hline & Dyn-Gumbel & $-0,03$ & $-0,94$ & 0,06 & 0,42 & 0,43 & 0,49 & 0,42 & 0,59 & 0,47 \\
\hline & Dyn-SJC & $-2,17$ & $-3,87$ & $-2,26$ & $-2,19$ & 1,28 & 1,46 & $-2,33$ & 1,07 & 1,13 \\
\hline \multirow{8}{*}{$\begin{array}{l}\text { Sulawesi } \\
\text { Tenggara }\end{array}$} & Stat-Gaussian & 0,03 & $-0,20$ & 0,04 & $-0,75$ & $-1,06$ & $-2,97$ & 0,00 & $-2,49$ & $-1,15$ \\
\hline & Stat-Clayton & 0,04 & $-0,20$ & 0,00 & $-0,28$ & 0,04 & 0,04 & 0,04 & $-2,39$ & 0,04 \\
\hline & Stat-Gumbel & 1,02 & 0,17 & 0,95 & $-0,75$ & 2,64 & 3,83 & 1,22 & $-2,13$ & 2,28 \\
\hline & Stat-SJC & 0,25 & $-0,07$ & 0,21 & $-0,76$ & 0,48 & 0,58 & 0,21 & $-2,97$ & 0,75 \\
\hline & Dyn-Gaussian & $-2,51$ & $-0,97$ & $-2,17$ & $-2,25$ & $-5,78$ & $-4,59$ & $-0,93$ & $-14,44$ & $-5,14$ \\
\hline & Dyn-Clayton & $-0,24$ & $-1,00$ & $-0,39$ & $-0,81$ & $-1,21$ & 0,14 & 0,00 & $-4,11$ & $-1,88$ \\
\hline & Dyn-Gumbel & 0,31 & $-1,07$ & 0,31 & $-0,92$ & 0,45 & 0,59 & 0,45 & $-6,88$ & 0,22 \\
\hline & Dyn-SJC & 0,49 & 0,09 & 0,41 & $-1,48$ & 1,14 & 1,68 & 0,57 & $-12,28$ & 1,17 \\
\hline \multirow{8}{*}{ Gorontalo } & Stat-Gaussian & $-0,08$ & $-0,41$ & $-0,09$ & 0,04 & $-0,03$ & $-0,20$ & $-0,08$ & $-0,07$ & $-0,05$ \\
\hline & Stat-Clayton & 0,04 & 0,04 & 0,04 & 0,04 & 0,04 & 0,04 & 0,04 & 0,04 & 0,04 \\
\hline & Stat-Gumbel & 1,39 & 2,14 & 1,41 & 0,22 & 1,35 & 1,84 & 1,61 & 1,42 & 1,69 \\
\hline & Stat-SJC & 0,29 & 0,32 & 0,29 & 0,03 & 0,34 & 0,27 & 0,35 & 0,18 & 0,27 \\
\hline & Dyn-Gaussian & $-0,28$ & $-0,81$ & $-0,29$ & $-1,55$ & $-0,18$ & $-0,50$ & $-0,28$ & $-0,27$ & $-0,21$ \\
\hline & Dyn-Clayton & $-0,82$ & $-0,79$ & $-0,82$ & $-0,77$ & $-0,79$ & $-0,80$ & $-0,77$ & $-0,75$ & $-0,75$ \\
\hline & Dyn-Gumbel & 0,59 & 0,59 & 0,59 & $-0,19$ & 0,59 & 0,59 & 0,59 & 0,59 & 0,59 \\
\hline & Dyn-SJC & $-1,24$ & 0,80 & $-1,23$ & $-1,27$ & $-1,21$ & 0,63 & $-1,15$ & 0,47 & $-1,21$ \\
\hline \multirow{8}{*}{ Sulawesi Barat } & Stat-Gaussian & $-0,07$ & $-0,13$ & $-0,04$ & $-0,01$ & 0,02 & $-0,09$ & $-0,03$ & 0,00 & 0,02 \\
\hline & Stat-Clayton & 0,04 & 0,04 & 0,04 & 0,04 & 0,04 & 0,04 & 0,04 & 0,04 & 0,04 \\
\hline & Stat-Gumbel & 1,31 & 1,57 & 1,16 & 1,36 & 0,17 & 1,18 & $-1,19$ & 0,01 & 0,35 \\
\hline & Stat-SJC & 0,29 & 0,35 & 0,45 & 0,46 & $-0,13$ & 0,32 & $-1,00$ & $-0,17$ & 0,01 \\
\hline & Dyn-Gaussian & $-0,25$ & $-0,33$ & $-0,20$ & $-0,13$ & $-0,79$ & $-0,31$ & $-1,42$ & $-1,43$ & $-0,85$ \\
\hline & Dyn-Clayton & $-0,81$ & $-0,84$ & $-0,80$ & $-0,77$ & $-0,86$ & $-0,86$ & $-0,77$ & $-0,77$ & $-0,76$ \\
\hline & Dyn-Gumbel & 0,56 & 0,59 & 0,46 & 0,59 & 0,03 & 0,56 & $-1,15$ & $-0,05$ & 0,21 \\
\hline & Dyn-SJC & $-1,26$ & $-1,15$ & $-1,59$ & $-1,23$ & $-2,34$ & $-1,26$ & $-1,61$ & $-1,56$ & $-0,64$ \\
\hline \multirow{8}{*}{ Maluku } & Stat-Gaussian & $-0,07$ & $-0,55$ & $-0,12$ & $-0,96$ & 0,04 & 0,04 & 0,03 & $-1,82$ & $-0,46$ \\
\hline & Stat-Clayton & $-0,59$ & $-0,44$ & 0,04 & 0,04 & 0,04 & $-0,32$ & $-1,76$ & 0,05 & 0,04 \\
\hline & Stat-Gumbel & 0,43 & 0,00 & 1,33 & 2,62 & 1,38 & 0,65 & 1,08 & 3,46 & 2,48 \\
\hline & Stat-SJC & $-0,34$ & $-0,28$ & 0,27 & 0,76 & 0,38 & $-0,28$ & $-2,11$ & 0,81 & 0,50 \\
\hline & Dyn-Gaussian & $-0,31$ & $-5,41$ & $-0,85$ & $-2,89$ & $-3,89$ & $-5,37$ & $-0,85$ & $-3,52$ & $-2,14$ \\
\hline & Dyn-Clayton & $-2,44$ & $-4,74$ & $-1,69$ & $-0,55$ & 0,01 & $-2,13$ & $-1,81$ & 0,15 & $-0,50$ \\
\hline & Dyn-Gumbel & $-1,81$ & $-0,33$ & 0,59 & 0,14 & 0,34 & $-1,81$ & 0,42 & 0,44 & 0,34 \\
\hline & Dyn-SJC & $-1,40$ & $-1,48$ & 0,58 & 1,23 & 0,52 & $-1,80$ & $-7,32$ & 1,71 & 1,05 \\
\hline
\end{tabular}




\begin{tabular}{|c|c|c|c|c|c|c|c|c|c|c|}
\hline \multirow[b]{2}{*}{ Province } & \multirow[b]{2}{*}{ Copula } & \multicolumn{9}{|c|}{ AIC Commodities } \\
\hline & & Paddy & Dryland paddy & Wet rice field & Maize & Mungbeans & Soybeans & Peanuts & $\begin{array}{c}\text { Sweet } \\
\text { potatoes }\end{array}$ & Cassava \\
\hline \multirow{8}{*}{ Maluku Utara } & Stat-Gaussian & $-0,06$ & $-0,08$ & 0,00 & 0,03 & $-0,25$ & 0,02 & 0,01 & $-0,06$ & $-0,03$ \\
\hline & Stat-Clayton & 0,04 & 0,04 & 0,04 & 0,04 & 0,04 & 0,04 & 0,04 & 0,04 & 0,04 \\
\hline & Stat-Gumbel & 1,34 & 1,38 & 1,23 & 1,10 & 1,48 & 1,16 & 1,19 & 1,26 & 1,24 \\
\hline & Stat-SJC & 0,29 & 0,34 & 0,42 & 0,35 & 0,31 & 0,18 & 0,40 & 0,33 & 0,45 \\
\hline & Dyn-Gaussian & $-0,24$ & $-0,28$ & $-0,12$ & $-0,06$ & $-0,60$ & $-0,07$ & $-0,11$ & $-0,23$ & $-0,19$ \\
\hline & Dyn-Clayton & $-0,81$ & $-0,81$ & $-0,75$ & $-0,73$ & $-0,82$ & $-0,72$ & $-0,71$ & $-0,69$ & $-0,71$ \\
\hline & Dyn-Gumbel & 0,58 & 0,58 & 0,58 & 0,57 & 0,59 & 0,58 & 0,58 & 0,59 & 0,59 \\
\hline & Dyn-SJC & 0,53 & $-1,23$ & $-1,28$ & $-1,34$ & 0,65 & 0,33 & $-1,42$ & $-1,25$ & $-1,25$ \\
\hline \multirow{8}{*}{ Papua Barat } & Stat-Gaussian & 0,00 & 0,03 & 0,02 & $-0,30$ & 0,03 & $-0,19$ & $-0,13$ & $-0,13$ & 0,03 \\
\hline & Stat-Clayton & 0,04 & 0,04 & 0,04 & 0,04 & 0,04 & 0,04 & 0,04 & 0,04 & 0,04 \\
\hline & Stat-Gumbel & $-0,69$ & 1,17 & $-0,61$ & 1,93 & 0,68 & 1,51 & 1,53 & 1,48 & $-0,19$ \\
\hline & Stat-SJC & $-0,74$ & 0,40 & $-0,62$ & 0,32 & 0,13 & 0,31 & 0,31 & 0,31 & $-0,20$ \\
\hline & Dyn-Gaussian & $-1,89$ & $-0,05$ & $-1,95$ & $-0,67$ & $-0,07$ & $-0,49$ & $-0,37$ & $-0,36$ & $-1,24$ \\
\hline & Dyn-Clayton & $-0,77$ & $-0,84$ & $-0,77$ & $-0,86$ & $-0,90$ & $-0,91$ & $-0,91$ & $-0,91$ & $-0,82$ \\
\hline & Dyn-Gumbel & $-0,63$ & 0,49 & $-0,55$ & 0,59 & 0,42 & 0,59 & 0,59 & 0,59 & $-0,18$ \\
\hline & Dyn-SJC & $-1,35$ & $-1,28$ & $-1,86$ & 0,75 & 0,27 & 0,64 & 0,63 & 0,62 & $-0,36$ \\
\hline \multirow{8}{*}{ Papua } & Stat-Gaussian & $-0,03$ & $-0,49$ & 0,03 & $-0,70$ & $-0,17$ & 0,01 & $-0,22$ & $-1,83$ & $-0,28$ \\
\hline & Stat-Clayton & 0,04 & 0,04 & 0,04 & 0,04 & 0,00 & 0,04 & 0,04 & $-3,33$ & 0,04 \\
\hline & Stat-Gumbel & 1,07 & 1,93 & 0,87 & 1,98 & 2,04 & 0,91 & 1,55 & $-0,68$ & 1,68 \\
\hline & Stat-SJC & 0,25 & 0,50 & 0,33 & 0,49 & 0,11 & 0,33 & 0,31 & $-3,13$ & 0,44 \\
\hline & Dyn-Gaussian & $-2,43$ & $-0,95$ & $-1,06$ & $-1,15$ & $-1,25$ & $-0,30$ & $-3,40$ & $-1,96$ & $-3,95$ \\
\hline & Dyn-Clayton & $-0,45$ & 0,13 & $-0,51$ & $-0,28$ & $-1,27$ & $-1,15$ & 0,13 & $-4,19$ & $-1,02$ \\
\hline & Dyn-Gumbel & 0,19 & 0,52 & 0,14 & 0,59 & 0,59 & 0,07 & 0,38 & $-1,11$ & 0,17 \\
\hline & Dyn-SJC & 0,57 & 0,99 & $-0,18$ & 0,97 & $-2,62$ & $-1,57$ & 0,78 & $-2,88$ & 0,87 \\
\hline
\end{tabular}

TABLE S.3. Parameter estimates of dynamic copula models

\begin{tabular}{|c|c|c|c|c|c|c|c|c|c|c|}
\hline Provinces & Parameters & Paddy & Dryland paddy & Wet rice field & Maize & Mung beans & Peanuts & Soybeans & Sweet potatoes & Cassava \\
\hline \multirow[t]{4}{*}{ Aceh } & Copula & Dyn-Clayton & Dyn-Gaussian & Dyn-SJC & Dyn-Clayton & Dyn-Gaussian & Dyn-Gaussian & Dyn-Gaussian & Dyn-Gaussian & Dyn-Gaussian \\
\hline & $\omega$ & -5.00 & -0.21 & $(-24.12,-19.25)$ & -5.00 & -0.21 & -0.45 & -0.71 & -0.15 & -0.85 \\
\hline & $\beta$ & 2.98 & 0.24 & $(-7.82,24.98)$ & 3.47 & -0.37 & -0.24 & -0.69 & -0.91 & 0.34 \\
\hline & $\alpha$ & 5.00 & 2.71 & $(-0.03,6.41)$ & 4.30 & 1.81 & 0.08 & 0.42 & 2.09 & -2.14 \\
\hline \multirow{4}{*}{$\begin{array}{l}\text { Sumatera } \\
\text { Utara }\end{array}$} & Copula & Dyn-Clayton & Dyn-Clayton & Dyn-Gaussian & Dyn-Gaussian & Dyn-Gaussian & Dyn-Clayton & Dyn-Gaussian & Dyn-Gaussian & Dyn-SJC \\
\hline & $\omega$ & -1.68 & -2.87 & -0.16 & -0.12 & -0.67 & -4.95 & -0.79 & 0.35 & $(-14.34,-20.97)$ \\
\hline & $\beta$ & 4.50 & -2.74 & -0.21 & -0.15 & -0.61 & 2.08 & -0.98 & -1.72 & $(-3.45,25.00)$ \\
\hline & $\alpha$ & -4.98 & 5.00 & 2.58 & 2.50 & 0.61 & 5.00 & -2.16 & 1.54 & $(-0.007,8.98)$ \\
\hline \multirow[t]{4}{*}{$\begin{array}{l}\text { Sumatera } \\
\text { Barat }\end{array}$} & Copula & Dyn-SJC & Dyn-Gaussian & Dyn-SJC & Dyn-SJC & Dyn-Gaussian & Dyn-Gaussian & Dyn-Gaussian & Dyn-Gaussian & Dyn-Gaussian \\
\hline & $\omega$ & $(-17.15,-20.42)$ & -0.57 & $(-14.90,-20.58)$ & $(-15.39,-20.06)$ & 0.07 & -0.35 & -0.07 & 0.12 & 0.01 \\
\hline & $\beta$ & $(0.02,24.98)$ & -3.16 & $(-0.0003,24.99)$ & $(-0.004,25.00)$ & -0.42 & -0.45 & -0.72 & -1.93 & -1.13 \\
\hline & $\alpha$ & $(-0.002,7.26)$ & -0.11 & $(0.0003,7.61)$ & $(0.0001,8.57)$ & 2.53 & 0.18 & 2.17 & 0.26 & -0.02 \\
\hline
\end{tabular}




\begin{tabular}{|c|c|c|c|c|c|c|c|c|c|c|}
\hline Provinces & Parameters & Paddy & Dryland paddy & Wet rice field & Maize & Mung beans & Peanuts & Soybeans & Sweet potatoes & Cassava \\
\hline \multirow[t]{4}{*}{ Riau } & Copula & Dyn-SJC & Dyn-Gaussian & Dyn-SJC & Dyn-Gaussian & Dyn-Gaussian & Dyn-Gaussian & Dyn-Gaussian & Dyn-Gaussian & Dyn-Gaussian \\
\hline & $\omega$ & $(0.85,-16.69)$ & -0.03 & $(-0.87,-12.39)$ & 0.03 & -0.36 & -0.56 & -0.69 & -0.04 & 0.00 \\
\hline & $\beta$ & $(-12.67,25.00)$ & -2.28 & $(-5.09,1.63)$ & 0.05 & -0.46 & -0.63 & -0.43 & -1.10 & -0.51 \\
\hline & $\alpha$ & $(4.64,3.19)$ & -1.11 & $(5.09,-0.02)$ & 2.21 & 0.18 & 0.78 & 0.03 & -0.82 & 2.15 \\
\hline \multirow[t]{4}{*}{ Jambi } & Copula & Dyn-SJC & Dyn-SJC & Dyn-SJC & Dyn-Gaussian & Dyn-Gaussian & Dyn-Gaussian & Dyn-SJC & Dyn-Gaussian & Dyn-Gaussian \\
\hline & $\omega$ & $(-23.03,-20.27)$ & $(1.36,-19.16)$ & $(-13.01,-20.29)$ & -0.75 & -0.62 & -0.90 & $\begin{array}{r}(-16.05,- \\
17.07)\end{array}$ & -0.39 & -0.11 \\
\hline & $\beta$ & $(2 \mathrm{E}-05,25.00)$ & $(-24.99,25.00)$ & $(-2.69,25.00)$ & 0.19 & -1.43 & -1.92 & $(-0.02,25.00)$ & -1.48 & -1.12 \\
\hline & $\alpha$ & $(-1 \mathrm{E}-05,7.79)$ & $(8.13,8.55)$ & $(-0.01,7.83)$ & -2.10 & 0.07 & -0.54 & $(0.0001,3.21)$ & 0.93 & 1.81 \\
\hline \multirow{4}{*}{$\begin{array}{l}\text { Sumatera } \\
\text { Selatan }\end{array}$} & Copula & Dyn-SJC & Dyn-Gaussian & Dyn-SJC & Dyn-Gaussian & Dyn-SJC & Dyn-SJC & Dyn-Gaussian & Dyn-Gaussian & Dyn-Gaussian \\
\hline & $\omega$ & $(-20.66,-21.34)$ & -0.39 & $(-14.14,-20.31)$ & 0.33 & $(-13.80,2.10)$ & $(2.07,-21.20)$ & -0.29 & -0.12 & -0.47 \\
\hline & $\beta$ & $(8 \mathrm{E}-05,25.00)$ & -0.63 & $(-3.21,25.00)$ & -1.91 & $(-0.05,-22.71)$ & $(-14.96,25.00)$ & -0.39 & -2.12 & -0.83 \\
\hline & $\alpha$ & $(-6.7 \mathrm{E}-6,9.61)$ & 3.28 & $(0.02,7.87)$ & 1.45 & $(0.001,6.66)$ & $(-12.24,8.78)$ & 0.35 & 0.00 & 0.79 \\
\hline \multirow[t]{4}{*}{ Bengkulu } & Copula & Dyn-Gaussian & Dyn-Gaussian & Dyn-SJC & Dyn-SJC & Dyn-Gaussian & Dyn-Gaussian & Dyn-Gaussian & Dyn-Gaussian & Dyn-Gaussian \\
\hline & $\omega$ & -0.11 & -0.27 & $(-24.40,-19.35)$ & $(6.12,-15.05)$ & -0.43 & -0.61 & -1.21 & -1.08 & -0.68 \\
\hline & $\beta$ & -1.52 & -0.63 & $(-12.49,24.90)$ & $(-25.00,-1.95)$ & -0.59 & -0.89 & -1.22 & -1.31 & -1.35 \\
\hline & $\alpha$ & -0.98 & 1.44 & $(-0.04,6.13)$ & $(-4.12,0.02)$ & 0.63 & 0.22 & 0.24 & 0.62 & 0.75 \\
\hline \multirow[t]{4}{*}{ Lampung } & Copula & Dyn-SJC & Dyn-SIC & Dyn-SJC & Dyn-SJC & Stat-Gaussian & Dyn-Gaussian & Dyn-Gaussian & Dyn-Gaussian & Dyn-SJC \\
\hline & $\omega$ & -13.09 & $(-16.11,4.94)$ & $(-24.98,-20.40)$ & $(1.14,-19.05)$ & & 0.03 & -0.10 & 0.15 & $(2.33,-20.44)$ \\
\hline & $\beta$ & -4.11 & $(-1.8 \mathrm{E}-3,-19.39)$ & $(-9.02,24.95)$ & $(-15.41,0.0002)$ & -0.12 & 0.09 & -0.88 & -1.53 & $(-18.04,-3 \mathrm{E}-5)$ \\
\hline & $\alpha$ & -0.01 & $(0.0002,-10.68)$ & $(-0.03,7.20)$ & $(5.20,-1 \mathrm{E}-5)$ & & 2.60 & 2.24 & 0.36 & $(5.26,7.51 \mathrm{E}-7)$ \\
\hline \multirow[t]{4}{*}{$\begin{array}{l}\text { Kep. Bangka } \\
\text { Belitung }\end{array}$} & Copula & Dyn-SIC & Dyn-Clayton & Dyn-SJC & Dyn-SJC & Dyn-Clayton & Dyn-Clayton & Dyn-Gaussian & Dyn-SJC & Dyn-SIC \\
\hline & $\omega$ & $(-13.33,-21.20)$ & -5.00 & $(-13.23,-21.20)$ & $(-15.06,-21.19)$ & -5.00 & -5.00 & -0.21 & $(-14.95,-21.19)$ & $(-13.89,-21.19)$ \\
\hline & $\beta$ & $(-4.14,25.00)$ & 2.23 & $(-4.03,25.00)$ & $(-1.01,25.00)$ & 2.42 & 2.26 & -0.18 & $(0.81,25.00)$ & $(-1.55,25.00)$ \\
\hline & $\alpha$ & $(-0.01,8.34)$ & 4.84 & $(-0.01,8.34)$ & $(-0.002,8.33)$ & 4.74 & 4.80 & 2.68 & $(-0.004,8.33)$ & $(0.001,8.34)$ \\
\hline \multirow[t]{4}{*}{ Kep. Riau } & Copula & Dyn-SJC & Dyn-SJC & Dyn-SJC & Dyn-Clayton & Dyn-SJC & Dyn-SJC & Dyn-Clayton & Dyn-SIC & Dyn-SJC \\
\hline & $\omega$ & $(-13.42,-21.20)$ & $(-11.94,-21.20)$ & $(-13.42,-21.20)$ & -5.00 & $(-12.94,-21.19)$ & $(-12.02,-21.19)$ & -5.00 & $(-11.34,-21.20)$ & $(-12.49,-21.19)$ \\
\hline & $\beta$ & $(-0.14,25.00)$ & $(-4.10,25.00)$ & $(-0.14,25.00)$ & 2.49 & $(-0.11,25.00)$ & $(-3.40,25.00)$ & 2.65 & $(-4.01,25.00)$ & $(-3.65,25.00)$ \\
\hline & $\alpha$ & $(0.001,8.35)$ & $(-0.01,8.34)$ & $(0.001,8.35)$ & 4.70 & $(0.01,8.34)$ & $(-0.01,8.34)$ & 4.65 & $(-0.01,8.34)$ & $(-0.01,8.34)$ \\
\hline \multirow[t]{4}{*}{ DKI Jakarta } & Copula & Dyn-Gaussian & Dyn-Gumbel & Dyn-Gaussian & Dyn-Gaussian & Dyn-SJC & Dyn-Gaussian & Dyn-SJC & Dyn-Clayton & Dyn-SJC \\
\hline & $\omega$ & -0.53 & -2.60 & -0.59 & 0.05 & $(-12.94,-21.19)$ & 0.04 & $\begin{array}{r}(-12.94,- \\
21.19)\end{array}$ & -3.04 & $(-8.58,-23.22)$ \\
\hline & $\beta$ & -5.28 & -1.02 & -4.98 & -0.22 & $(-0.11,25.00)$ & -0.23 & $(-0.11,25.00)$ & -1.96 & $(25.00,-0.0002)$ \\
\hline & $\alpha$ & 1.01 & 5.00 & 0.96 & 1.86 & $(0.01,8.34)$ & 1.87 & $(0.01,8.34)$ & 5.00 & $(-8.45,3.2 \mathrm{E}-19)$ \\
\hline
\end{tabular}




\begin{tabular}{|c|c|c|c|c|c|c|c|c|c|c|}
\hline Provinces & Parameters & Paddy & Dryland paddy & Wet rice field & Maize & Mung beans & Peanuts & Soybeans & Sweet potatoes & Cassava \\
\hline \multirow[t]{4}{*}{ Jawa Barat } & Copula & Dyn-Gaussian & Dyn-Gaussian & Dyn-Gaussian & Dyn-Gaussian & Dyn-Gaussian & Dyn-Gaussian & Dyn-Gaussian & Dyn-SJC & Dyn-Gaussian \\
\hline & $\omega$ & -0.11 & 0.01 & -0.09 & 0.01 & -0.14 & -0.48 & -0.23 & $(-11.65,-7.48)$ & -0.22 \\
\hline & $\beta$ & -0.35 & -1.27 & -0.31 & -0.79 & -1.13 & -1.16 & -0.97 & $(19.50,4.82)$ & -1.73 \\
\hline & $\alpha$ & 2.44 & -0.38 & 2.43 & 2.24 & 0.36 & -0.16 & 2.77 & $(6.31,0.01)$ & -0.55 \\
\hline \multirow[t]{4}{*}{ Jawa Tengah } & Copula & Dyn-Clayton & Dyn-Gaussian & Dyn-Gaussian & Dyn-SJC & Dyn-Clayton & Dyn-Gaussian & Dyn-Gaussian & Dyn-SJC & Dyn-Gaussian \\
\hline & $\omega$ & -4.85 & -0.03 & -0.02 & $(-23.88,-12.82)$ & -4.61 & -0.35 & -0.10 & $(-2.06,-19.31)$ & -0.20 \\
\hline & $\beta$ & 3.53 & -0.50 & -0.55 & $(24.49,20.31)$ & 5.00 & -2.31 & -0.85 & $(-24.78,0.0004)$ & -1.32 \\
\hline & $\alpha$ & 5.00 & 2.12 & 1.83 & $(2.44,9.82)$ & 4.66 & -0.67 & 2.54 & $(19.40,-2.5 \mathrm{E}-5)$ & -0.19 \\
\hline \multirow{4}{*}{$\begin{array}{l}\text { DI } \\
\text { Yogyakarta }\end{array}$} & Copula & Dyn-SJC & Dyn-SJC & Dyn-SJC & Dyn-SJC & Dyn-Gaussian & Dyn-Gaussian & Dyn-Gaussian & Dyn-Gaussian & Dyn-SJC \\
\hline & $\omega$ & $(-11.63,-20.37)$ & $(-19.27,-20.58)$ & $(-15.92,-20.28)$ & $(2.95,-18.38)$ & 0.12 & -0.39 & -0.24 & -0.24 & $(3.30,-20.99)$ \\
\hline & $\beta$ & $(-1.60,25.00)$ & $(-5.78,25.00)$ & $(0.0003,24.98)$ & $(-23.98,24.91)$ & -0.67 & -0.64 & -0.27 & -4.23 & $(-22.91,25.00)$ \\
\hline & $\alpha$ & $(-0.004,6.77)$ & $(-0.02,8.52)$ & $(-0.0001,6.96)$ & $(7.81,7.71)$ & 1.36 & -0.09 & 0.17 & -1.09 & $(5.57,9.60)$ \\
\hline \multirow[t]{4}{*}{ Jawa Timur } & Copula & Dyn-SJC & Dyn-Clayton & Dyn-SJC & Dyn-SJC & Dyn-SJC & Dyn-SJC & Dyn-Gaussian & Dyn-Gumbel & Dyn-Gaussian \\
\hline & $\omega$ & $(-11.42,3)$ & -5.00 & $(-14.43,2.87)$ & $(-14.02,-20.80)$ & $(-18.08,-21.20)$ & $(-21.14,-19.97)$ & -1.33 & 5.00 & -0.44 \\
\hline & $\beta$ & $(-12.07,-25.00)$ & 3.32 & $(-5.24,-25.00)$ & $(-0.03,25.00)$ & $(-4.22,25.00)$ & $(0.0002,25.00)$ & -3.09 & -3.89 & -0.90 \\
\hline & $\alpha$ & $(-0.04,5.42)$ & 4.82 & $(-0.01,5.33)$ & $(0.0001,9.47)$ & $(-0.01,8.36)$ & $(7.95 \mathrm{E}-07,7.79)$ & -0.49 & -4.77 & 0.04 \\
\hline \multirow[t]{4}{*}{ Banten } & Copula & Dyn-Clayton & Dyn-SJC & Dyn-SJC & Dyn-SJC & Dyn-Clayton & Dyn-SJC & Dyn-Clayton & Dyn-SJC & Dyn-SJC \\
\hline & $\omega$ & -5.00 & $(-2.19,-16.88)$ & $(-7.36,-21.19)$ & $(-16.11,-21.19)$ & -5.00 & $(-2.68,-15.08)$ & -5.00 & $(-12.49,-21.20)$ & $(-14.43,-21.21)$ \\
\hline & $\beta$ & 2.45 & $(-2.32,0.015)$ & $(-8.95,25.00)$ & $(-5.25,25.00)$ & 2.28 & $(-0.21,-0.001)$ & 2.49 & $(-3.73,25.00)$ & $(-0.02,25.00)$ \\
\hline & $\alpha$ & 4.73 & $(7.42,0.0002)$ & $(0.0082,8.34)$ & $(0.005,8.33)$ & 4.78 & $(6.87,0.0002)$ & 4.69 & $(-0.02,8.35)$ & $(0.0002,8.36)$ \\
\hline \multirow[t]{4}{*}{ Bali } & Copula & Dyn-Clayton & Dyn-SJC & Dyn-SJC & Dyn-Gaussian & Dyn-Clayton & Dyn-Gaussian & Dyn-Gaussian & Dyn-SJC & Dyn-Gaussian \\
\hline & $\omega$ & -0.98 & $(-4.57,-20.31)$ & $(-14.12,7.02)$ & -0.40 & -4.99 & -0.21 & -0.15 & $(-8.59,-15.43)$ & -0.07 \\
\hline & $\beta$ & 2.64 & $(15.77,-1.7 \mathrm{E}-5)$ & $(-2.36,-25.00)$ & -1.76 & 2.35 & -0.82 & -0.38 & $(24.99,10.43)$ & -1.86 \\
\hline & $\alpha$ & -5.00 & $(-5.63,-1.4 \mathrm{E}-7)$ & $(-1.91,-3.78)$ & 0.83 & 5.00 & 0.22 & 1.48 & $(-20.36,2.15)$ & -1.79 \\
\hline \multirow{4}{*}{$\begin{array}{l}\text { Nusa } \\
\text { Tenggara } \\
\text { Barat }\end{array}$} & Copula & Dyn-SJC & Dyn-Gaussian & Dyn-SJC & Dyn-Gaussian & Dyn-Gumbel & Dyn-Gaussian & Dyn-Gaussian & Dyn-Gaussian & Dyn-Gaussian \\
\hline & $\omega$ & $(-21.95,-19.77)$ & 0.30 & $(-18.29,-19.80)$ & 0.34 & -3.69 & -0.11 & -0.49 & 0.00 & -0.14 \\
\hline & $\beta$ & $(-7.54,24.98)$ & -1.23 & $(-0.0008,24.99)$ & 0.73 & 2.23 & -0.13 & -1.10 & 2.21 & 3.40 \\
\hline & $\alpha$ & $(-0.02,6.19)$ & 1.36 & $(1.03 \mathrm{E}-05,6.52)$ & -0.45 & -5.00 & 0.52 & 0.86 & -2.53 & -2.58 \\
\hline \multirow{4}{*}{$\begin{array}{l}\text { Nusa } \\
\text { Tenggara } \\
\text { Timur }\end{array}$} & Copula & Dyn-SJC & Dyn-Gaussian & Dyn-SJC & Dyn-SJC & Dyn-Gaussian & Dyn-SJC & Dyn-Gaussian & Dyn-Gaussian & Dyn-SJC \\
\hline & $\omega$ & $(-20.89,-20.95)$ & -0.08 & $(-16.61,-21.05)$ & $(-22.54,-18.44)$ & 0.04 & $(6.03,-18.37)$ & -0.98 & 0.88 & $(6.42,-20.68)$ \\
\hline & $\beta$ & $(1.4 \mathrm{E}-4,25.00)$ & -2.42 & $(-8.9 \mathrm{E}-5,25.00)$ & $(-5 \mathrm{E}-5,25.00)$ & 0.10 & $(-24.99,25.00)$ & -1.69 & -2.85 & $(-22.11,25.00)$ \\
\hline & $\alpha$ & $(-2 \mathrm{E}-5,9.09)$ & 1.23 & $(-4.4 \mathrm{E}-05,9.26)$ & $(-6.4 \mathrm{E}-18,6.14)$ & 2.05 & $(-8.91,5.65)$ & 0.39 & 0.42 & $(-4.40,8.49)$ \\
\hline
\end{tabular}




\begin{tabular}{|c|c|c|c|c|c|c|c|c|c|c|}
\hline Provinces & Parameters & Paddy & Dryland paddy & Wet rice field & Maize & Mung beans & Peanuts & Soybeans & Sweet potatoes & Cassava \\
\hline \multirow{4}{*}{$\begin{array}{l}\text { Kalimantan } \\
\text { Barat }\end{array}$} & Copula & Dyn-SJC & Dyn-Gaussian & Dyn-SJC & Dyn-SJC & Dyn-Gaussian & Dyn-Gaussian & Dyn-Gaussian & Dyn-Gaussian & Dyn-Gaussian \\
\hline & $\omega$ & $(6.06,-21.20)$ & -0.55 & $(2.93,-21.20)$ & $(0.66,-13.11)$ & 1.41 & -0.47 & -0.09 & -0.68 & 0.25 \\
\hline & $\beta$ & $(-25.00,25.00)$ & -0.75 & $(-24.99,25.00)$ & $(-12.78,0.04)$ & -4.50 & -0.67 & -0.40 & -0.58 & -0.23 \\
\hline & $\alpha$ & $(-7.51,8.35)$ & 0.36 & $(8.92,8.35)$ & $(6.75,-0.002)$ & -0.64 & 0.27 & 1.90 & 0.21 & 2.90 \\
\hline \multirow{4}{*}{$\begin{array}{l}\text { Kalimantan } \\
\text { Tengah }\end{array}$} & Copula & Dyn-Gaussian & Dyn-SJC & Dyn-Gaussian & Dyn-SJC & Dyn-Gaussian & Dyn-Gaussian & Dyn-Gaussian & Dyn-Clayton & Dyn-SJC \\
\hline & $\omega$ & -0.27 & $(-13.77,-18.76)$ & -0.32 & $(-7.99,-18.58)$ & -0.30 & -0.08 & 0.07 & -4.83 & $(-21.69,-19.14)$ \\
\hline & $\beta$ & -0.56 & $(-0.01,25.00)$ & -0.44 & $(1.04,24.73)$ & -0.39 & -1.08 & 0.07 & 2.00 & $(0.00002,24.99)$ \\
\hline & $\alpha$ & 0.34 & $(-0.0002,6.45)$ & 0.20 & $(-0.002,6.79)$ & 0.38 & 0.69 & 2.45 & 5.00 & $(3.89 \mathrm{E}-07,6.25)$ \\
\hline \multirow[t]{4}{*}{$\begin{array}{l}\text { Kalimantan } \\
\text { Selatan }\end{array}$} & Copula & Dyn-Clayton & Dyn-SJC & Dyn-Clayton & Dyn-Gaussian & Dyn-SJC & Dyn-SJC & Dyn-Gaussian & Dyn-Gaussian & Dyn-Gaussian \\
\hline & $\omega$ & -5.00 & $(-19.53,-16.85)$ & -5.00 & -0.41 & $(-19.69,4.04)$ & $(-11.48,-20.91)$ & -1.18 & -1.16 & -0.63 \\
\hline & $\beta$ & 3.17 & $(0.0001,24.80)$ & 3.10 & -1.02 & $(-2 \mathrm{E}-4,-14.59)$ & $(-6.97,25.00)$ & -1.33 & -1.11 & -0.37 \\
\hline & $\alpha$ & 4.48 & $(-4 \mathrm{E}-06,4.43)$ & 4.46 & -1.28 & $(-9.04 \mathrm{E}-6,-6.20)$ & $(-0.01,8.93)$ & -0.43 & -2.05 & -2.10 \\
\hline \multirow{4}{*}{$\begin{array}{l}\text { Kalimantan } \\
\text { Timur }\end{array}$} & Copula & Dyn-Gaussian & Dyn-Gaussian & Dyn-SJC & Dyn-Gaussian & Dyn-Gaussian & Dyn-Gaussian & Dyn-Gaussian & Dyn-Gaussian & Dyn-Gaussian \\
\hline & $\omega$ & 0.02 & -1.26 & $(0.87,-13.01)$ & -0.82 & -0.52 & -0.30 & -0.46 & 0.09 & -0.54 \\
\hline & $\beta$ & 0.04 & -1.28 & $(-14.22,-0.02)$ & -0.55 & -0.40 & -0.38 & -0.80 & 0.12 & -0.75 \\
\hline & $\alpha$ & 2.26 & -1.23 & $(7.41,0.01)$ & -1.98 & 0.04 & 0.10 & 0.48 & 2.39 & -0.89 \\
\hline \multirow{4}{*}{$\begin{array}{l}\text { Kalimantan } \\
\text { Utara }\end{array}$} & Copula & Dyn-SJC & Dyn-Clayton & Dyn-SJC & Dyn-SJC & Dyn-Clayton & Dyn-Clayton & Dyn-Clayton & Dyn-SJC & Dyn-Clayton \\
\hline & $\omega$ & $(-16.77,-21.19)$ & -5.00 & $(-12.41,-21.19)$ & $(-16.49,-21.19)$ & -5.00 & -5.00 & -5.00 & $(-12.41,-21.19)$ & -5.00 \\
\hline & $\beta$ & $(-0.49,25.00)$ & 2.63 & $(-1.46,25.00)$ & $(-0.03,25.00)$ & 2.64 & 2.65 & 2.52 & $(-1.46,25.00)$ & 2.56 \\
\hline & $\alpha$ & $(0.49,8.34)$ & 4.66 & $(0.003,8.34)$ & $(-0.002,8.34)$ & 4.66 & 4.65 & 4.71 & $(0.033,8.34)$ & 4.69 \\
\hline \multirow{4}{*}{$\begin{array}{l}\text { Sulawesi } \\
\text { Utara }\end{array}$} & Copula & Dyn-SJC & Dyn-Gumbel & Dyn-SJC & Dyn-Clayton & Dyn-Gaussian & Dyn-Gumbel & Dyn-Gaussian & Dyn-Gaussian & Dyn-SJC \\
\hline & $\omega$ & $(-14.50,-20.89)$ & 0.32 & $(-12.94,-20.89)$ & -1.72 & -0.47 & -3.96 & -0.73 & -0.07 & $(-12.19,-13.75)$ \\
\hline & $\beta$ & $(-3.45,25.00)$ & -1.00 & $(-3.60,25.00)$ & 0.87 & -0.87 & 2.66 & -0.91 & -1.61 & $(25.00,-0.02)$ \\
\hline & $\alpha$ & $(-0.01,8.83)$ & -5.00 & $(-0.02,8.83)$ & 1.29 & 0.15 & -4.99 & 0.42 & -0.85 & $(4.79,0.0002)$ \\
\hline \multirow{4}{*}{$\begin{array}{l}\text { Sulawesi } \\
\text { Tengah }\end{array}$} & Copula & Dyn-Clayton & Dyn-Gaussian & Dyn-Clayton & Dyn-SJC & Dyn-Gaussian & Dyn-Gaussian & Dyn-Gaussian & Dyn-Gaussian & Dyn-Gaussian \\
\hline & $\omega$ & -5.00 & 1.06 & -5.00 & $(-13.63,2.00)$ & -0.31 & 0.13 & -1.45 & 0.02 & -0.08 \\
\hline & $\beta$ & 2.38 & -5.25 & 2.45 & $(-2.32,-24.99)$ & -0.29 & 0.17 & -1.49 & -0.02 & -0.73 \\
\hline & $\alpha$ & 4.80 & -0.90 & 4.71 & $(-0.003,6.99)$ & 0.86 & 1.55 & -1.04 & 2.21 & 2.18 \\
\hline \multirow{4}{*}{$\begin{array}{l}\text { Sulawesi } \\
\text { Selatan }\end{array}$} & Copula & Dyn-Gaussian & Dyn-SJC & Dyn-Gaussian & Dyn-SJC & Dyn-Gaussian & Dyn-SJC & Dyn-Gaussian & Stat-Gaussian & Dyn-Gaussian \\
\hline & $\omega$ & -0.12 & $(-12.94,3.57)$ & -0.13 & $(-19.98,-19.64)$ & -1.28 & $(-21.15,-18.37)$ & -1.11 & & -0.40 \\
\hline & $\beta$ & -1.12 & $(-1.66,-25.00)$ & -1.13 & $(-0.0002,25.00)$ & -2.13 & $(-0.0002,25.00)$ & -1.27 & -0.11 & -0.52 \\
\hline & $\alpha$ & -0.78 & $(-0.002,-2.98)$ & -0.79 & $(2.78 \mathrm{E}-06,8.28)$ & -0.81 & $(-1.04 \mathrm{E}-6,6.35)$ & 0.09 & & -0.16 \\
\hline
\end{tabular}




\begin{tabular}{|c|c|c|c|c|c|c|c|c|c|c|}
\hline Provinces & Parameters & Paddy & Dryland paddy & Wet rice field & Maize & Mung beans & Peanuts & Soybeans & Sweet potatoes & Cassava \\
\hline \multirow{4}{*}{$\begin{array}{l}\text { Sulawesi } \\
\text { Tenggara }\end{array}$} & Copula & Dyn-Gaussian & Dyn-Gumbel & Dyn-Gaussian & Dyn-Gaussian & Dyn-Gaussian & Dyn-Gaussian & Dyn-Gaussian & Dyn-Gaussian & Dyn-Gaussian \\
\hline & $\omega$ & -0.22 & -5.00 & -0.17 & -0.21 & -0.89 & -0.35 & -0.70 & 2.05 & -0.65 \\
\hline & $\beta$ & -2.11 & 0.57 & -2.00 & -0.16 & -1.91 & -1.11 & -0.56 & -6.00 & -1.38 \\
\hline & $\alpha$ & -0.99 & 5.00 & -0.92 & 2.72 & -0.06 & -0.85 & 0.42 & -0.23 & 0.54 \\
\hline \multirow[t]{4}{*}{ Gorontalo } & Copula & Dyn-SJC & Dyn-Gaussian & Dyn-SJC & Dyn-Gaussian & Dyn-SJC & Dyn-SJC & Dyn-Clayton & Dyn-Clayton & Dyn-SJC \\
\hline & $\omega$ & $(-14.59,-21.19)$ & -0.25 & $(-12.84,-21.19)$ & -0.14 & $(-14.26,-21.20)$ & $(-16.50,-21.20)$ & -5.00 & -5.00 & $(-14.90,-21.19)$ \\
\hline & $\beta$ & $(-0.003,25.00)$ & -0.30 & $(-4.67,25.00)$ & -0.15 & $(-0.02,25.00)$ & $(-0.01,25.00)$ & 2.29 & 2.29 & $(-0.40,25.00)$ \\
\hline & $\alpha$ & $(-0.0001,8.34)$ & 0.21 & $(-0.11,8.34)$ & 2.54 & $(0.001,8.35)$ & $(0.01,8.35)$ & 4.79 & 4.77 & $(-0.0009,8.34)$ \\
\hline \multirow[t]{4}{*}{$\begin{array}{l}\text { Sulawesi } \\
\text { Barat }\end{array}$} & Copula & Dyn-SJC & Dyn-SJC & Dyn-SJC & Dyn-SJC & Dyn-SJC & Dyn-SJC & Dyn-SJC & Dyn-SJC & Dyn-Gaussian \\
\hline & $\omega$ & $(-12.68,-21.19)$ & $(-12.64,-21.19)$ & $(5.69,-21.19)$ & $(-12.51,-21.20)$ & $(6.24,-21.18)$ & $(0.14,-13.24)$ & $\begin{array}{r}(-13.73,- \\
21.19)\end{array}$ & $(6.67,-13.34)$ & 0.01 \\
\hline & $\beta$ & $(-0.30,25.00)$ & $(-0.02,25.00)$ & $(-25.00,25.00)$ & $(-3.62,25.00)$ & $(-24.98,25.00)$ & $(-12.95,-0.060$ & $(-1.35,25.00)$ & $(-25.00,0.0001)$ & 0.00 \\
\hline & $\alpha$ & $(-0.005,8.34)$ & $(0.02,8.34)$ & $(-8.85,8.34)$ & $(-0.01,8.34)$ & $(-10.35,8.33)$ & $(10.05,0.004)$ & $(0.10,8.34)$ & $(-8.02,0.0004)$ & 2.03 \\
\hline \multirow[t]{4}{*}{ Maluku } & Copula & Dyn-Clayton & Dyn-Gaussian & Dyn-Clayton & Dyn-Gaussian & Dyn-Gaussian & Dyn-SJC & Dyn-Gaussian & Dyn-Gaussian & Dyn-Gaussian \\
\hline & $\omega$ & -0.32 & 0.22 & -4.87 & -0.77 & -0.70 & $(-23.35,-15.46)$ & -0.32 & -0.91 & -0.47 \\
\hline & $\beta$ & 0.91 & -1.97 & 2.58 & 1.21 & -5.88 & $(0.00003,24.94)$ & -3.37 & -3.07 & -1.50 \\
\hline & $\alpha$ & -5.00 & 1.39 & 5.00 & -1.92 & -1.04 & $(1.09 \mathrm{E}-16,8.62)$ & -0.85 & -1.24 & 0.24 \\
\hline \multirow{4}{*}{$\begin{array}{l}\text { Maluku } \\
\text { Utara }\end{array}$} & Copula & Dyn-Clayton & Dyn-SJC & Dyn-SJC & Dyn-SJC & Dyn-Clayton & Dyn-SJC & Dyn-Clayton & Dyn-SJC & Dyn-SJC \\
\hline & $\omega$ & -5.00 & $(-12.94,-21.19)$ & $(-15.03,-21.20)$ & $(-10.57,-21.20)$ & -5.00 & $(4.74,-21.20)$ & -5.00 & $(-13.42,-21.20)$ & $(-7.87,-21.19)$ \\
\hline & $\beta$ & 2.47 & $(-0.11,25.00)$ & $(0.30,25.00)$ & $(-3.34,25.00)$ & 2.58 & $(-24.99,25.00)$ & 2.47 & $(-0.14,25.00)$ & $(-7.53,25.00)$ \\
\hline & $\alpha$ & 4.72 & $(0.01,8.34)$ & $(-0.45,8.34)$ & $(-0.01,8.35)$ & 4.68 & $(18.18,8.35)$ & 4.70 & $(0.001,8.35)$ & $(-0.02,8.34)$ \\
\hline \multirow[t]{4}{*}{ Papua Barat } & Copula & Dyn-Gaussian & Dyn-SJC & Dyn-Gaussian & Dyn-Clayton & Dyn-Clayton & Dyn-Clayton & Dyn-Clayton & Dyn-Clayton & Dyn-Gaussian \\
\hline & $\omega$ & -0.16 & $(-11.43,-21.20)$ & -0.17 & -5.00 & -5.00 & -5.00 & -5.00 & -5.00 & -0.13 \\
\hline & $\beta$ & -0.15 & $(-6.54,25.00)$ & -0.16 & 2.30 & 2.15 & 2.18 & 2.21 & 2.18 & -0.13 \\
\hline & $\alpha$ & 2.59 & $(0.05,8.35)$ & 2.60 & 4.81 & 4.87 & 4.87 & 4.85 & 4.87 & 2.56 \\
\hline \multirow[t]{4}{*}{ Papua } & Copula & Dyn-Gaussian & Dyn-Gaussian & Dyn-Gaussian & Dyn-Gaussian & Dyn-SJC & Dyn-Gaussian & Dyn-SJC & Dyn-Clayton & Dyn-Gaussian \\
\hline & $\omega$ & -0.23 & -0.47 & -0.72 & -0.36 & $(-23.07,-20.59)$ & -0.85 & $\begin{array}{r}(-12.24,- \\
21.21)\end{array}$ & -0.08 & -0.05 \\
\hline & $\beta$ & -0.28 & -0.67 & -0.29 & -0.45 & $(0.00004,24.97)$ & -1.99 & $(-5.37,25.00)$ & -0.29 & -0.16 \\
\hline & $\alpha$ & 2.70 & -0.66 & -1.99 & -0.05 & $(-2.5 \mathrm{E}-19,7.73)$ & -0.77 & $(-0.03,8.82)$ & -2.71 & 2.51 \\
\hline
\end{tabular}

